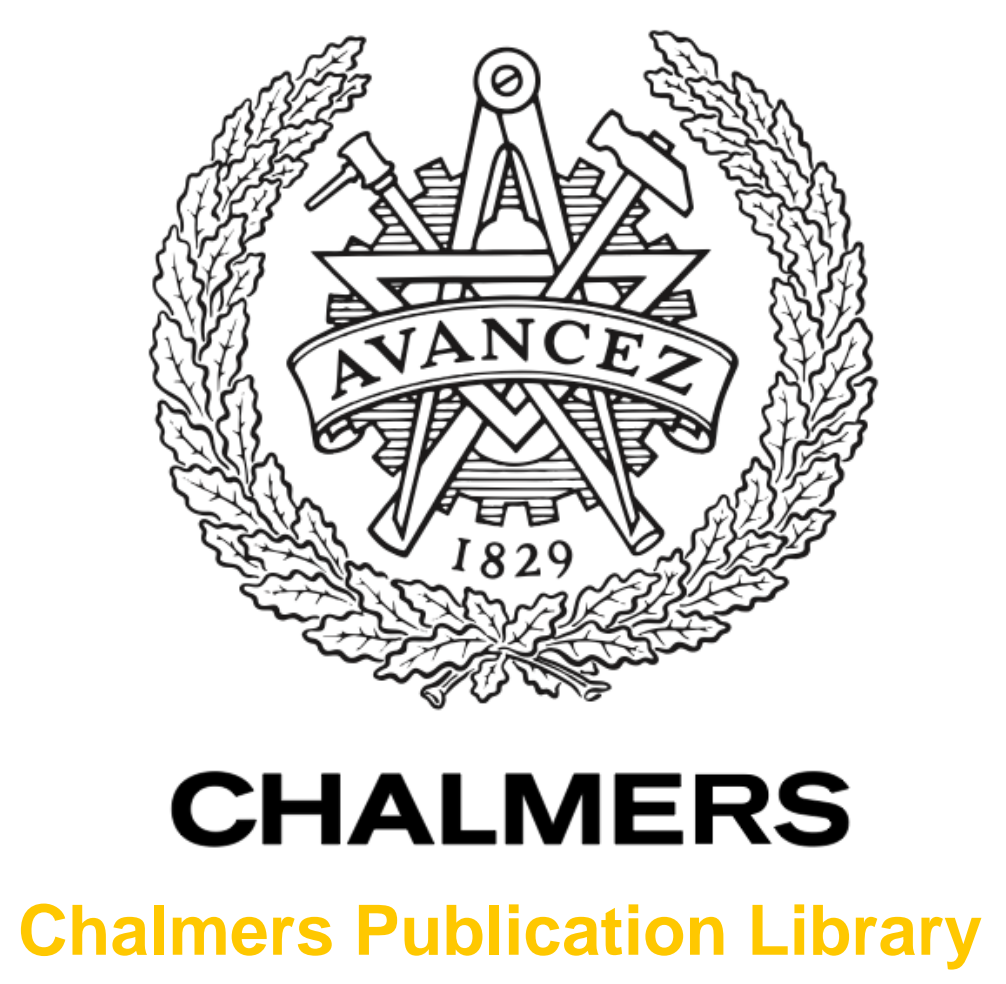

\title{
Combined Oxides of Iron, Manganese and Silica as Oxygen Carriers for Chemical- Looping Combustion
}

This document has been downloaded from Chalmers Publication Library (CPL). It is the author's version of a work that was accepted for publication in:

Fuel processing technology (ISSN: 0378-3820)

Citation for the published paper:

Källen, M. ; Hallberg, P. ; Rydén, M. (2014) "Combined Oxides of Iron, Manganese and Silica as Oxygen Carriers for Chemical-Looping Combustion". Fuel processing technology, vol. 124(August 2014), pp. 87-96.

http://dx.doi.org/10.1016/j.fuproc.2014.02.020

Downloaded from: http://publications.lib.chalmers.se/publication/196357

Notice: Changes introduced as a result of publishing processes such as copy-editing and formatting may not be reflected in this document. For a definitive version of this work, please refer to the published source. Please note that access to the published version might require a subscription. 


\title{
Combined Oxides of Iron, Manganese and Silica as Oxygen Carriers for Chemical-Looping Combustion
}

\author{
Malin Källén*, Peter Hallberg, Magnus Rydén, Tobias Mattisson, Anders Lyngfelt \\ Department of Energy and Environment \\ Chalmers University of Technology \\ SE-412 96, Gothenburg, Sweden
}

\begin{abstract}
Spray-dried particles with the chemical compositions of $\mathrm{Fe}_{0.66} \mathrm{Mn}_{1.33} \mathrm{SiO}_{3}$ and $\mathrm{FeMnSiO}_{3}$ have been examined as oxygen carrier materials for chemical-looping combustion. The performance of the materials was examined in oxygen release experiments and during fuel operation with natural gas and syngas. The experiments were carried out in a fluidized-bed chemical-looping reactor system designed for a thermal power of $300 \mathrm{~W}$. The reactor system includes an air reactor and a fuel reactor, as well as loop seals and means for circulation of the oxygen carrier particles. Both materials were able to release gas phase oxygen in inert atmosphere at temperatures between 800$950^{\circ} \mathrm{C}$, and with approximately equal oxygen concentrations. $\mathrm{Fe}_{0.66} \mathrm{Mn}_{1.33} \mathrm{SiO}_{3}$ provided higher conversion of natural gas as compared to $\mathrm{FeMnSiO}_{3}$ and the fuel conversion increased with temperature for both materials. During natural gas operation with $\mathrm{Fe}_{0.66} \mathrm{Mn}_{1.33} \mathrm{SiO}_{3}$ the conversion reached $100 \%$ at around $950^{\circ} \mathrm{C}$ with a fuel reactor inventory of $235 \mathrm{~kg} / \mathrm{MW}$. The fuel conversion was improved when the solids inventory was increased; this improvement could especially be observed for $\mathrm{FeMnSiO}_{3}$ as the fuel conversion was lower for this material. $\mathrm{Fe}_{0.66} \mathrm{Mn}_{1.33} \mathrm{SiO}_{3}$ provided higher fuel conversion than $\mathrm{FeMnSiO}_{3}$ also when syngas was used as fuel. The fuel conversion increased with temperature for both materials and full conversion was reached above $800^{\circ} \mathrm{C}$ with a fuel reactor inventory of $225 \mathrm{~kg} / \mathrm{MW}$ for $\mathrm{Fe}_{0.66} \mathrm{Mn}_{1.33} \mathrm{SiO}_{3}$, while $\mathrm{FeMnSiO}_{3}$ was incapable of providing full conversion. A rather large elutriation of fines and a significant change in particle size distribution could be observed during operation for both materials.

Both materials could work as oxygen carrier for chemical-looping with oxygen uncoupling. $\mathrm{Fe}_{0.66} \mathrm{Mn}_{1.33} \mathrm{SiO}_{3}$ would be preferred as it has higher conversion of both syngas and natural gas, but the attrition behavior of the material would need to be further investigated.
\end{abstract}

Keywords: chemical-looping combustion, chemical-looping with oxygen uncoupling, combined oxides, iron manganese silica oxides, carbon dioxide capture 


\begin{tabular}{|c|c|}
\hline \multicolumn{2}{|c|}{ Nomenclature } \\
\hline$A R$ & air reactor \\
\hline$C C S$ & carbon capture and storage \\
\hline$C L C$ & chemical-looping combustion \\
\hline$C L O U$ & chemical-looping with oxygen uncoupling \\
\hline $\mathrm{F}_{\mathrm{AR}}$ & inlet flow to air reactor $\left(\mathrm{L}_{\mathrm{N}} / \mathrm{min}\right)$ \\
\hline $\mathrm{F}_{\mathrm{FR}}$ & inlet flow to fuel reactor $\left(\mathrm{L}_{\mathrm{N}} / \mathrm{min}\right)$ \\
\hline$F R$ & fuel reactor \\
\hline$M e_{x} O_{y-1}$ & reduced oxygen carrier \\
\hline$M e_{x} O_{y}$ & oxidized oxygen carrier \\
\hline$x_{i}$ & gas concentration, $\mathrm{i}=\mathrm{CO}, \mathrm{CO}_{2}, \mathrm{CH}_{4}, \mathrm{O}_{2}, \mathrm{~N}_{2}(\%)$ \\
\hline$\gamma_{\mathrm{CO}_{2}}$ & $\mathrm{CO}_{2}$ yield (-) \\
\hline
\end{tabular}




\section{Introduction}

Global warming and the increasing concentrations of greenhouse gases in the atmosphere pose significant threats to today's society [1]. Many different mitigation solutions have been proposed. Carbon dioxide capture and storage (CCS) is often mentioned as an important strategy. CCS is a method to reduce emissions of $\mathrm{CO}_{2}$ to the atmosphere which involves separation of carbon dioxide in the flue gases from point-sources such as industries and power plants, transportation to a storage location and subsequent long-term storage, for example in depleted gas fields or deep saline aquifers [2].

The aim of this study was to investigate the performance of combined iron, manganese and silica as oxygen carrier for the carbon capture technology chemical-looping combustion. Combined oxides of manganese-iron and of manganese-silica have promising thermodynamic possibilities to work as oxygen carriers for chemical-looping combustion and for chemical-looping with oxygen uncoupling. Ores with high content of manganese, iron and silica are common and this study could provide an increased level of understanding of how such mixed oxides work as oxygen carriers. One aim is the possible use of natural ores which would provide benefits regarding cost and availability of future oxygen carriers. Another aim is manufacturing high reactivity oxygen carriers from low cost raw materials. Manufactured oxygen carriers of manganese, iron and silica could be fairly cheap and should be neither toxic nor environmentally harmful. These materials would be very favorable for combustion of solids fuels since they would probably not be affected by the sulfur in the fuel and the low cost of the material would be advantageous as material would be lost in the ash removal.

\subsection{Chemical-Looping Combustion}

Chemical-looping combustion (CLC) is a carbon dioxide capture technology which has developed fast in the last years. Worldwide more than 700 oxygen carrier materials have been examined and the total continuous operation now amounts to more than $4000 \mathrm{~h}$ in chemicallooping units ranging from $300 \mathrm{~W}$ to $140 \mathrm{~kW}$, see recent review articles by Lyngfelt [3] and Adanez et.al. [4] for an overview. In chemical-looping combustion, the oxygen needed for oxidation of the fuel is supplied by a solid oxygen carrier. The oxygen carrier is oxidized by air in one reactor and reduced by the fuel in another reactor. The oxygen carrier material is continuously circulated between the two reactors. The exhaust gas from the air reactor (AR) consists of oxygen depleted air and the exhaust gas from the fuel reactor (FR) ideally consists only of carbon dioxide and steam, and the latter may easily be condensed to obtain an almost pure stream of carbon dioxide, see Figure 1. In this way carbon dioxide is inherently captured without any direct energy penalty for gas separation. 


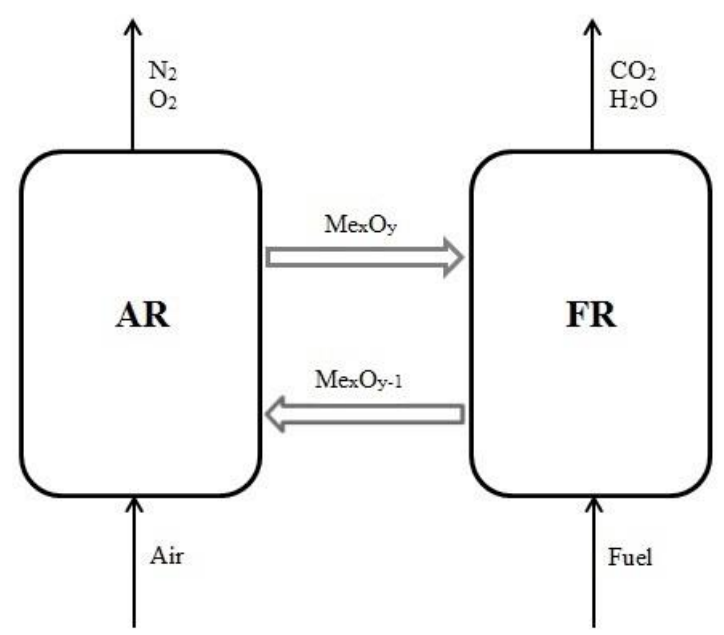

Figure 1. A schematic overview of the CLC process.

The fuel will react with the oxygen carrier according to:

$$
(2 n+m) \mathrm{Me}_{x} \mathrm{O}_{y}+\mathrm{C}_{n} \mathrm{H}_{2 m} \rightarrow(2 n+m) \mathrm{Me}_{x} \mathrm{O}_{y-1}+m \mathrm{H}_{2} \mathrm{O}+n \mathrm{CO}_{2}
$$

Where $\mathrm{Me}_{\mathrm{x}} \mathrm{O}_{\mathrm{y}}$ represents a metal oxide and $\mathrm{Me}_{\mathrm{x}} \mathrm{O}_{\mathrm{y}-1}$ represents a metal or reduced metal oxide. The oxygen carrier will then be reoxidized in the air reactor according to:

$$
M e_{x} O_{y-1}+\frac{1}{2} O_{2} \rightarrow M e_{x} O_{y}
$$

The amount of energy released in the two reactions is equal to that for normal combustion of the same fuel. This is evident since the sum of equation (1) and equation (2) is normal combustion of the fuel with oxygen.

Chemical-looping with oxygen uncoupling (CLOU) is a process closely related to chemicallooping combustion, which was originally proposed by Mattisson et.al. [5]. The combustion of the fuel takes place in two steps. First the oxygen carrier releases gas phase oxygen according to:

$$
\mathrm{Me}_{x} \mathrm{O}_{y} \rightarrow \mathrm{Me}_{x} \mathrm{O}_{y-1}+\frac{1}{2} \mathrm{O}_{2}
$$

The fuel may then be oxidized by gaseous oxygen released by the oxygen carrier, rather than by direct reaction with the oxygen carrier. This is especially beneficial for solid fuels where char otherwise needs to be gasified to be able to react with the solid oxygen carrier, and char gasification is slow compared to direct reaction between char and oxygen. In chemical-looping with oxygen uncoupling the char instead reacts directly with gaseous oxygen released by the oxygen carrier. The use of an oxygen carrier capable to release gas phase oxygen could decrease or even eliminate the need for additional measures such as oxygen polishing to reach full conversion of the fuel. This has been demonstrated during continuous operation with bituminous coal by Abad et. al. [6]. CLOU could also prove to be favourable for oxidation of gaseous fuels, 
since the presence of gas phase oxygen could be expected to facilitate full combustion even with insufficient mixing of gases and solids. Presence of small amounts of gaseous oxygen in the freeboard can effectively oxidize any combustible gases that pass the bed because of bubbles or poor mixing. Azimi et. al. showed the impact of the oxygen release during combustion of wood chips in inert atmosphere and could compare this to the combustion of methane with the same oxygen carrier particles [7]. Continuous operation with natural gas as fuel with complete conversion of the fuel and excess oxygen in the outlet stream has been reported by Källén et. al. [8].

In order to illustrate the possible advantages of an oxygen carrier which releases oxygen, a comparison between a very reactive material without CLOU properties and a less reactive material with CLOU properties can be made. The two materials are a spray-dried nickel oxide material here referred to as $\mathrm{N}$-Vito which has been used during $1000 \mathrm{~h}$ of operation in a $10 \mathrm{~kW}$ unit [9] and a calcium manganate material, here referred to as $\mathrm{C} 14$, which has been examined in the same $10 \mathrm{~kW}$ unit [8]. A kinetic determination of the two materials was made at CSIC under similar conditions, whereby conversion versus time was studied in TGA in e.g. $15 \%$ methane [10, 11]. A reactivity comparison indicates that methane reacts more than three times faster with $\mathrm{N}$ Vito, as compared to $\mathrm{C} 14$. In theory, the N-Vito material could reach full conversion with a solids inventory of 10-20 kg [11], whereas in reality it reached $97 \%$ conversion in the $10 \mathrm{~kW}$ unit with a solids inventory corresponding to around $500 \mathrm{~kg} / \mathrm{MW}$ [9], and $89 \%$ conversion in a 120 $\mathrm{kW}$ unit with around $133 \mathrm{~kg} / \mathrm{MW}$ [12]. The discrepancy has been attributed to the inadequate contact between gas and solids due to by-passing gas in the bubble phase. Despite the markedly lower reactivity of $\mathrm{C} 14$, it has been possible to reach full conversion in the $10 \mathrm{~kW}$ unit [8] as well as in the $120 \mathrm{~kW}$ unit [13].

There are a number of requirements which an oxygen carrier material should fulfil. Firstly, oxidation and reduction must occur at sufficient rate at the desired temperature level. This is important in order to minimize the amount of material required in each reactor. The oxygen transfer capacity, i.e. the amount of oxygen (measured in weight\%) which the oxygen carrier can deliver to the fuel per cycle, should be sufficient. If the oxygen carrier is used for chemicallooping with oxygen uncoupling, the rate of oxygen release is also an important parameter. The oxygen carrier particles also need to have sufficient mechanical and chemical integrity to keep attrition and elutriation of fines at low rates. The particles should also be inert towards fuel impurities in order to avoid deactivation and loss of reactivity. Furthermore, the cost and the environmental impact of the material should be at reasonable levels.

The most commonly proposed way to realise chemical-looping combustion is using two interconnected fluidized beds. In this case, the oxygen carrier in the form of particles with good fluidization properties is circulated between the two fluidized beds. By using this method much of the knowledge and experience from fluidized bed boilers (CFB) can be utilized. 


\subsection{Combined Iron-Manganese-Silica Oxygen Carriers}

The most investigated oxygen carrier materials for chemical-looping combustion are based on oxides of nickel, copper, iron and manganese. Suitable oxygen carrier materials have been identified by thermodynamic analysis [14]. The interest in combined or mixed oxides and CLOU materials has been growing the past few years, see review articles by Lyngfelt and Mattisson [15] and Adanez et.al [4]. In theory, manganese oxides should work as oxygen carrier in CLOU, but the relevant equilibrium concentrations for CLOU occur at relatively low temperatures (below $800^{\circ} \mathrm{C}$ ) [5]. However, the thermodynamic properties of manganese oxides can be altered by combining the manganese with other metals [16].

Oxygen carrier materials of combined manganese and silica have been examined by Jing et. al. with good results [17]. Combined oxides of manganese and iron showed good oxygen carrier properties in TGA experiments [18] and combined oxides of manganese-iron, manganese-nickel and manganese-silica were operated in a batch fluidized reactor where manganese-iron materials showed both oxygen release behavior and good conversion of methane [19]. The thermodynamics of the system of iron oxide and manganese oxide have been examined in previous studies [20-22]. There are several more recent studies of combining manganese and iron to create better oxygen carriers for CLOU, both in a fluidized batch reactor $[7,23,24]$ and in a circulating fluidized bed reactor [25]. Combined oxides of manganese, iron and silica have been studied in a batch fluidized reactor showing promising results [26]. A thorough investigation of the thermodynamics of the systems of manganese-iron and manganese-silica has been made by Rydén et.al. [16].

A phase diagram of mixed oxides of manganese, iron and silica can be seen in Figure 2. The phase diagram has been calculated with the software FactSage 6.3 using the FToxid database. The oxygen partial pressure was set to $0.05 \mathrm{~atm}$ which would correspond to an expected outlet concentration of oxygen from the air reactor. The molar fraction of silica was set to $33 \%$, which is the silica fraction of the examined oxygen carriers $\mathrm{FeMnSiO}_{3}$ and $\mathrm{Fe}_{0.66} \mathrm{Mn}_{1.33} \mathrm{SiO}_{3}$ which are marked in the diagram as solid vertical lines. 


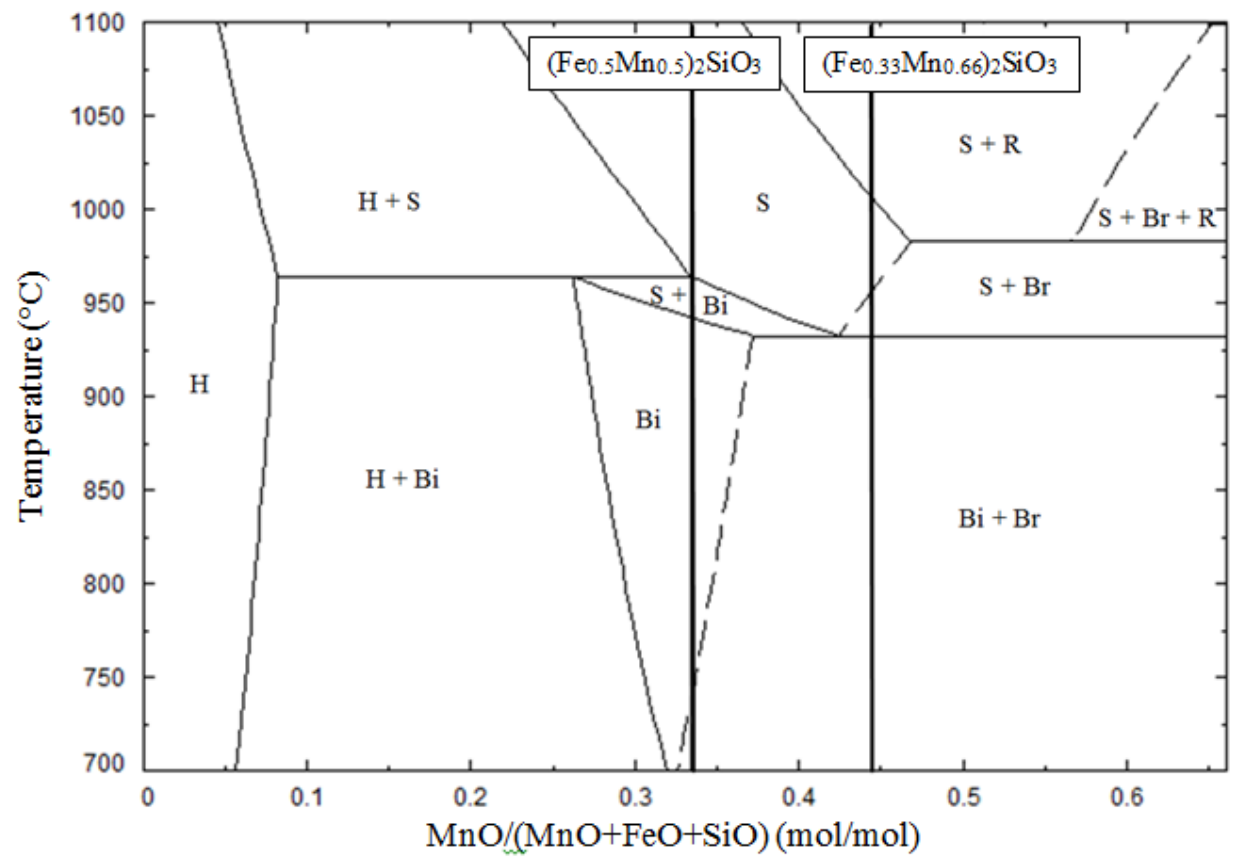

Bi : Bixbyite, $\left(\mathrm{Mn}_{\mathrm{x}} \mathrm{Fe}_{1-\mathrm{x}}\right)_{2} \mathrm{O}_{3}$ $\mathrm{Br}$ : Braunite, $\mathrm{Mn}_{7} \mathrm{SiO}_{12}$ $\mathrm{H}$ : Hematite, $\left(\mathrm{Fe}_{\mathrm{x}} \mathrm{Mn}_{1-\mathrm{x}}\right)_{2} \mathrm{O}_{3}$ $\mathrm{R}$ : Rhodonite, $\mathrm{MnSiO}_{3}$ $\mathrm{S}:$ Spinel, $\left(\mathrm{Mn}_{\mathrm{x}} \mathrm{Fe}_{1-\mathrm{x}}\right)_{3} \mathrm{O}_{4}$

Figure 2. Phase diagram of $\mathrm{MnO}-\mathrm{FeO}-\mathrm{SiO}$ in an oxygen partial pressure of $5 \%$. The molar fraction of silica is fixed at $33 \%$. Silica is also present as various forms of $\mathrm{SiO}_{2}$, but these are not marked in the phase diagram. The vertical lines denote the composition of the oxygen carriers studied in this work.

The calculated phase diagram is consistent with the phase diagram of the manganese-iron systems $[22,24]$. The dashed lines in the phase diagram represent the main effect of the presence of silica as it marks the transition to braunite. Braunite is the mineral name for $\mathrm{Mn}_{7} \mathrm{SiO}_{12}$ with small impurities of other metals, but is used here for the pure phase. Another silica containing phase in this system is rhodonite consisting of $\mathrm{MnSiO}_{3}$ with dilute amounts of $\mathrm{FeSiO}_{3}$. Silica is also present as various forms of $\mathrm{SiO}_{2}$, but these are not marked in the phase diagram. Both hematite and bixbyite are mixtures of $\mathrm{Mn}_{2} \mathrm{O}_{3}$ and $\mathrm{Fe}_{2} \mathrm{O}_{3}$, where $\mathrm{Mn}_{2} \mathrm{O}_{3}$ is the main component in bixbyite and $\mathrm{Fe}_{2} \mathrm{O}_{3}$ is the main component in hematite. The spinel marked in the diagram has the chemical formula $\left(\mathrm{Mn}_{\mathrm{x}} \mathrm{Fe}_{1-\mathrm{x}}\right)_{3} \mathrm{O}_{4}$.

The phase transition between bixbyite and spinel occurs at temperatures relevant for chemicallooping:

$$
6(\mathrm{Mn}, \mathrm{Fe})_{2} \mathrm{O}_{3} \leftrightarrow 4(\mathrm{Mn}, \mathrm{Fe})_{3} \mathrm{O}_{4}+\mathrm{O}_{2}
$$

This reaction could be induced either by a change in temperature or a change in oxygen partial pressure. A lower oxygen partial pressure lowers the temperature for the transition and a higher partial pressure of oxygen increases the temperature for the transition. According to Figure 2, the phase transition between bixbyite and spinel should be complete for $\mathrm{Fe}_{0.66} \mathrm{Mn}_{1.33} \mathrm{SiO}_{3}$ at around $930^{\circ} \mathrm{C}$, while for $\mathrm{FeMnSiO}_{3}$ bixbyite is present up to $965^{\circ} \mathrm{C}$. For $\mathrm{Fe}_{0.66} \mathrm{Mn}_{1.33} \mathrm{SiO}_{3}$ braunite can be present up to $950^{\circ} \mathrm{C}$ in addition to bixbyite and spinel. 
It is also possible that the transition from braunite to rhodonite could be interesting for chemicallooping:

$$
2 / 3 \mathrm{Mn}_{7} \mathrm{SiO}_{12}+4 \mathrm{SiO}_{2} \leftrightarrow 14 / 3 \mathrm{MnSiO}_{3}+\mathrm{O}_{2}
$$

This reaction would occur at around $980-1000^{\circ} \mathrm{C}$ and would only be relevant for oxygen carriers with a high content of manganese.

\section{Experimental}

\subsection{Oxygen Carriers}

The examined oxygen carrier particles have the chemical compositions $\mathrm{Fe}_{0.66} \mathrm{Mn}_{1.33} \mathrm{SiO}_{3}$ and $\mathrm{FeMnSiO}_{3}$. Both materials were manufactured by VITO in Belgium by spray drying, followed by sintering at $1100^{\circ} \mathrm{C}$ for four hours. The size distributions of the fresh materials were determined by sieving and can be seen in Figure 3.

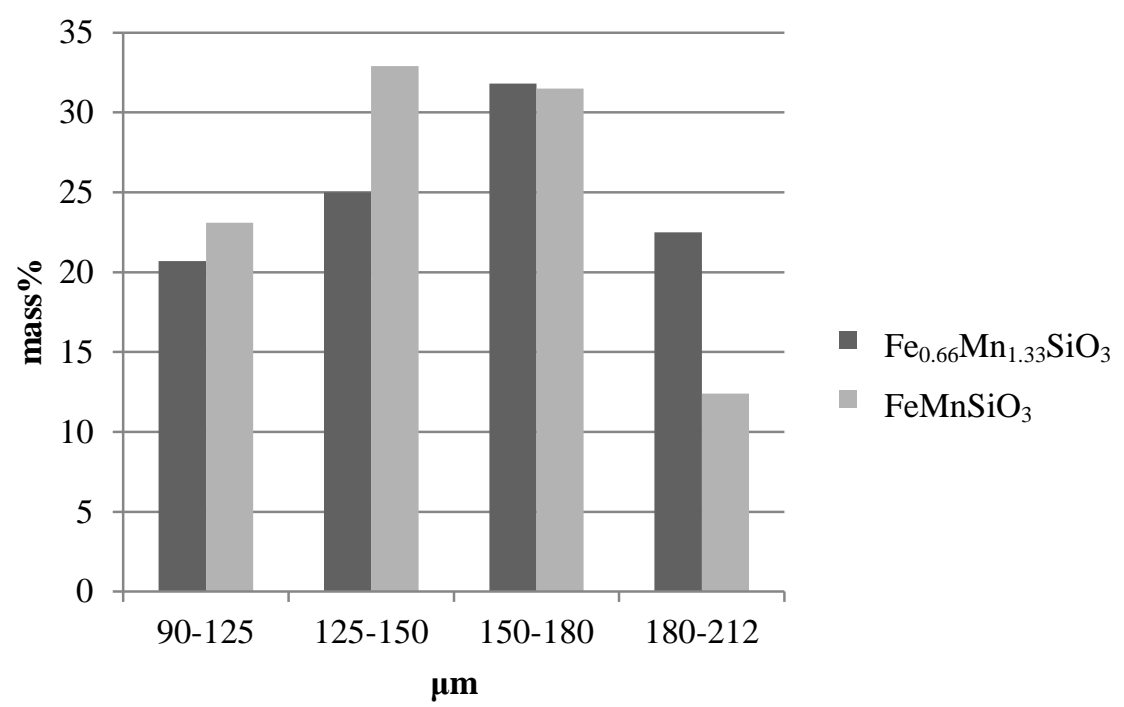

Figure 3. Particle size distribution of the fresh oxygen carrier particles.

The properties of the fresh particles have been summarized in Table 1. The crushing strength is defined as the average force needed to crush a particle in the size span 180-250 $\mu \mathrm{m}$. The reported bulk density is calculated simply as the weight divided by the volume. The reported attrition index is calculated from measurements using a customized jet cup, see the article by Rydén et. al. for a description of the jet cup and methodology [27]. This method has been suggested and used as an alternative to the ASTM D5757-95 method. The results from this method are used here as a comparison to the experimental attrition behaviour of the materials. 
Table 1. Properties of the fresh oxygen carrier particles.

\begin{tabular}{lccc} 
Material & $\begin{array}{c}\text { Bulk density } \\
\left(\mathbf{k g} / \mathbf{m}^{3}\right)\end{array}$ & $\begin{array}{c}\text { Crushing Strength } \\
(\mathbf{N})\end{array}$ & $\begin{array}{c}\text { Attrition index } \\
(\mathbf{m a s s} \% / \mathbf{h})\end{array}$ \\
\hline $\mathrm{Fe}_{\mathbf{0 . 6 6}} \mathbf{M n}_{1.33} \mathrm{SiO}_{\mathbf{3}}$ & 1026 & 1.0 & 32.3 \\
$\mathrm{FeMnSiO}_{\mathbf{3}}$ & 1240 & 1.2 & 1.2 \\
\hline
\end{tabular}

\subsection{Experimental setup}

The experiments were carried out in a circulating fluidized-bed laboratory reactor designed for a thermal power of $300 \mathrm{~W}$. A three-dimensional schematic picture of the reactor is shown in Figure 4.

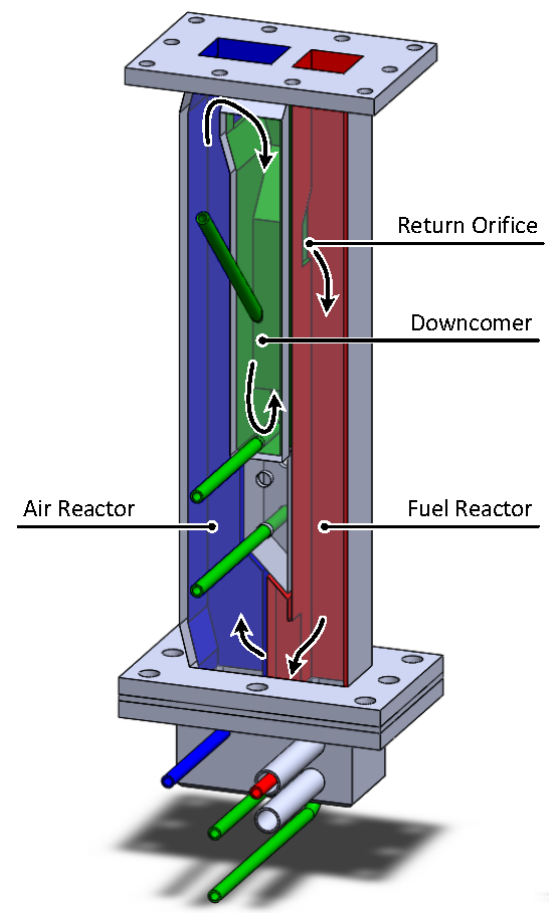

Figure 4. A three-dimensional schematic picture of the fluidized-bed reactor.

The reactor consists of two compartments, the air reactor and the fuel reactor. The air reactor has a lower bed section where the cross section is larger than in the riser section above the bed. The precondition for the circulation to occur is that the gas velocity in the air reactor is high enough to carry the particles up from the bed surface. When the gas with the suspended particles exits the air reactor it enters a separation box where the gas velocity decreases due to an increased cross sectional area. This low-velocity section results in a separation of gas and particles, which will fall down towards the air reactor. However, a certain fraction of particles enter the downcomer between the air and fuel reactor. The downcomer works as a J-type loop seal with an overflow exit into the fuel reactor. The particles return to the air reactor through the lower loop seal located in the bottom of the system between the wind box of the air reactor and the wind box of the fuel reactor. 
The air reactor is fluidized with air and the fuel reactor is fluidized with natural gas or syngas during fuel operation and with carbon dioxide during oxygen release experiments. Porous quartz plates are used as gas distributors in both the air reactor and the fuel reactor. The downcomer and the lower loop seal are fluidized with argon which is added through small holes in the pipes which can be seen in Figure 4. Since the reactor system has a high area to volume ratio it will generate large heat losses and therefore the reactor system is enclosed in an electric furnace to keep the desired temperature.

The temperature is measured with one thermocouple in the air reactor and one in the fuel reactor. The thermocouples are located approximately $1 \mathrm{~cm}$ above the distributer plate in each reactor. The pressure drops in the reactor system are measured by pressure transducers in the air reactor, fuel reactor and in the downcomer. The pressure drops are measured in order to be able to assess the fluidization behaviour and the particle inventory in the different parts of the reactor system.

The outlet of the fuel reactor is connected to a water seal with a 1-2 $\mathrm{cm}$ column of water giving a slightly higher pressure in the fuel reactor than in the air reactor. A part of each outlet stream is lead through a particle filter and a gas conditioning unit before the gas analyzers. Methane, carbon monoxide and carbon dioxide are measured with IR-sensors while oxygen is measured with a paramagnetic sensor. The outlet from the fuel reactor is also analyzed with a gas chromatograph which measures hydrogen and nitrogen, as well as the previously mentioned gases. The entire reactor setup has been thoroughly described in previous publications [28, 29]. Syngas $\left(50 \% \mathrm{CO}\right.$ and $\left.50 \% \mathrm{H}_{2}\right)$ and natural gas were used as fuels. The composition of the natural gas is shown in Table 2 .

Table 2. Annual average composition for 2012 of the natural gas as reported by the gas supplier.

\begin{tabular}{lllllllllll} 
Species & $\mathrm{CH}_{4}$ & $\mathrm{C}_{2} \mathrm{H}_{6}$ & $\mathrm{C}_{3} \mathrm{H}_{8}$ & $\begin{array}{l}\text { iso- } \\
\mathrm{C}_{4} \mathrm{H}_{10}\end{array}$ & $\begin{array}{l}\mathrm{n}- \\
\mathrm{C}_{4} \mathrm{H}_{10}\end{array}$ & $\begin{array}{l}\text { iso- } \\
\mathrm{C}_{5} \mathrm{H}_{12}\end{array}$ & $\begin{array}{l}\mathrm{n}- \\
\mathrm{C}_{5} \mathrm{H}_{12}\end{array}$ & $\mathrm{C}_{6} \mathrm{H}_{14}+$ & $\mathrm{N}_{2}$ & $\mathrm{CO}_{2}$ \\
\hline Mole\% & 88.84 & 6.11 & 2.44 & 0.37 & 0.54 & 0.13 & 0.08 & 0.06 & 0.36 & 1.06 \\
\hline
\end{tabular}

Solid carbon may be formed in the wind box of the fuel reactor during fuel combustion which can cause operational problems. One way solid carbon can be formed is through the Boudouard reaction:

$$
2 \mathrm{CO} \leftrightarrow \mathrm{C}+\mathrm{CO}_{2}
$$

Solid carbon may also form by hydrocarbon decomposition:

$$
C_{n} H_{m} \leftrightarrow n C+(m / 2) H_{2}
$$




\subsection{Data evaluation}

All gas concentrations were measured on dry basis. From the measurements the $\mathrm{CO}_{2}$ yield was calculated to evaluate the combustion performance. The $\mathrm{CO}_{2}$ yield is defined as the amount of carbon dioxide formed divided by the total amount of carbon species in the outlet flow according to:

$$
\gamma_{\mathrm{CO}_{2}}=\frac{x_{\mathrm{CO}_{2}}}{x_{\mathrm{CO}_{2}}+x_{\mathrm{CO}}+x_{\mathrm{CH}_{4}}}
$$

The data evaluation was complicated by gas leakage between the reactor compartments. The leakage occurred both ways and was detected by measuring carbon dioxide in the air reactor and nitrogen in the fuel reactor. The carbon dioxide fraction in the air reactor does not interfere much with the data analysis. However, the air leakage to the fuel reactor affects the results both for oxygen release and combustion performance. The gas leakage has been located to the top of the reactor by injecting tracer gas in the pressure measurement taps. It was therefore assumed that the air which leaked into the fuel reactor had the same concentrations of oxygen and nitrogen as the outlet air from the air reactor. The fraction of oxygen leaking from the air reactor is quantified by the nitrogen concentration out of the fuel reactor and the oxygen concentration out of the air reactor:

$$
x_{O_{2}, \text { leakage }}=x_{N_{2}, F R} \frac{x_{O_{2}, A R, \text { out }}}{x_{N_{2}, \text { AR,out }}}
$$

In the same way the oxygen fraction related to the release of oxygen from the oxygen carrier particles is calculated as:

$$
x_{O_{2}, \text { released }}=x_{O_{2}, F R}-x_{N_{2}, F R} \frac{x_{O_{2}, A R, \text { out }}}{x_{N_{2}, A R, \text { out }}}
$$

The calculated oxygen leakage was subtracted from the measured oxygen concentrations during the oxygen release experiments. The fuel operation results were not recalculated for oxygen leakage, which could imply that the fuel conversion should be slightly lower. The oxygen leakage measured during these experiments has likely increased the $\mathrm{CO}_{2}$ yield by 1-2\%.

\subsection{Methodology}

The amount of solids added to the reactor system was determined by the bulk density of the particles. The surface of the fluidized bed in the air reactor should be above the height where the cross section area is reduced. The amount of material was chosen to achieve a fluidized bed height in the air reactor slightly above the height where the cross section is changed. Following this method, $200 \mathrm{~g}$ of $\mathrm{Fe}_{0.66} \mathrm{Mn}_{1.33} \mathrm{SiO}_{3}$ and $240 \mathrm{~g}$ of $\mathrm{FeMnSiO}_{3}$ were used as starting inventories for the experiments. The inventory was increased during the fuel operation with 25 weight $\%$ in both cases to investigate the influence of solids inventory. 
The reactor system was heated from room temperature at the beginning of each day of experiments and cooled down again at the end of the day. The electric furnace was heating the system during all experiments to control the temperature.

First oxygen release experiments were conducted with air as oxidizing gas in the air reactor. The experiment was then repeated with $5 \%$ oxygen in nitrogen as oxidizing gas in the air reactor. The total gas flow in the air reactor was kept constant in order not to influence the circulation rate of solids. The experiments with $5 \%$ oxygen in the air reactor were done in order to examine operation at what constitutes a realistic outlet oxygen concentration in a full-scale system. Basically, it is important that oxidation is possible at a reasonably low $\mathrm{O}_{2}$ partial pressure. The process would otherwise need to operate at a high air ratio, which would increase heat losses and capital costs. Oxygen release experiments were also carried out after fuel operation in order to investigate if the particle properties were changed irreversibly during fuel operation. The fuel reactor was fluidized with carbon dioxide during all oxygen release experiments.

The experiments with syngas as fuel were carried out in periods of 15-20 min. This was necessary due to carbon formation in the wind box of the fuel reactor, see reaction (5). After each batch of syngas the fuel reactor was fluidized with air to oxidize the accumulated carbon in the wind box. The fuel reactor temperature was varied during these experiments, in order to examine its impact on fuel conversion.

The experiments with natural gas were carried out in continuous operation. The fuel reactor temperature and the fuel flow were varied during these experiments. The air reactor was fluidized with air during all fuel experiments.

An overview of the experiments carried out with $\mathrm{Fe}_{0.66} \mathrm{Mn}_{1.33} \mathrm{SiO}_{3}$ can be seen in Table 3 and an overview of the experiments with $\mathrm{FeMnSiO}_{3}$ can be seen in Table 4. Each day of operation was named with a Roman number in consecutive order with a subscript for the iron to manganese ratio of the oxygen carrier used.

Table 3. An overview of the experiments carried out with $\mathrm{Fe}_{0.66} \mathrm{Mn}_{1.33} \mathrm{SiO}_{3}$.

\begin{tabular}{lccccl} 
Day & $\begin{array}{c}\text { Time with fuel } \\
(\mathbf{h})\end{array}$ & $\begin{array}{c}\text { FR temperature } \\
\left({ }^{\circ} \mathbf{C}\right)\end{array}$ & $\begin{array}{c}\mathbf{F}_{\mathbf{A R}} \\
\left(\mathbf{L}_{\mathbf{N}} / \mathbf{m i n}\right)\end{array}$ & $\begin{array}{l}\mathbf{F}_{\mathbf{F R}} \\
\left(\mathbf{L}_{\mathbf{N}} / \mathbf{m i n}\right)\end{array}$ & Comment \\
\hline $\mathbf{I}_{\mathbf{1 : 2}}$ & 0 & $650-950$ & 4 & 0 & CLOU with air and 5\% $\mathrm{O}_{2}$ \\
II $_{\mathbf{1 : 2}}$ & 1.7 & $700-950$ & 8 & 1.2 & Syngas \\
III $_{1: 2}$ & 3.2 & $700-950$ & 7 & 0.3 & Natural gas \\
IV $_{\mathbf{1 : 2}}$ & 1.9 & $\sim 950$ & 7 & $0.3-0.4$ & Natural gas \\
$\mathbf{V}_{\mathbf{1 : 2}}$ & 1.4 & $\sim 950$ & 7 & $0.3-0.4$ & Natural gas \\
VI $_{\mathbf{1 : 2}}$ & 0 & $650-950$ & 4 & 0 & CLOU with air \\
\hline
\end{tabular}


Table 4. An overview of the experiments carried out with $\mathrm{FeMnSiO}_{3}$.

\begin{tabular}{lccccl} 
Day & $\begin{array}{c}\text { Time with fuel } \\
(\mathbf{h})\end{array}$ & $\begin{array}{c}\text { FR temperature } \\
\left({ }^{\circ} \mathbf{C}\right)\end{array}$ & $\begin{array}{l}\mathbf{F}_{\mathbf{A R}} \\
\left(\mathbf{L}_{\mathbf{N}} / \mathbf{m i n}\right)\end{array}$ & $\begin{array}{l}\mathbf{F}_{\mathbf{F R}} \\
\left(\mathbf{L}_{\mathbf{N}} / \mathbf{m i n}\right)\end{array}$ & Comment \\
\hline $\mathbf{I}_{1: 1}$ & 0 & $650-950$ & 4 & 0 & CLOU with air \\
II $_{1: 1}$ & 0 & $650-950$ & 4 & 0 & CLOU with $5 \% \mathrm{O}_{2}$ \\
III $_{1: 1}$ & 3.6 & $750-1000$ & 6,7 & 0.3 & Natural gas \\
IV $_{1: 1}$ & 6.3 & $900-1000$ & 7 & 0.3 & Natural gas \\
V $_{1: 1}$ & 2.4 & 950 & 7 & 0.3 & Natural gas \\
VI $_{1: 1}$ & 2.1 & $750-950,950$ & 4,7 & $0,0.3$ & CLOU with air, natural gas \\
VII $_{1: 1}$ & 1.7 & $700-950$ & 8 & 1.2 & Syngas \\
\hline
\end{tabular}

\section{Results and Discussion}

\subsection{Oxygen Release}

Three oxygen release experiments were carried out with $\mathrm{Fe}_{0.66} \mathrm{Mn}_{1.33} \mathrm{SiO}_{3}$ and the results can be seen in Figure 5. The temperature of the furnace was increased stepwise with 50 degrees in all experiments. As can be seen in the figure, no oxygen release was observed until the temperature exceeded $850^{\circ} \mathrm{C}$ in the experiments before fuel operation. The oxygen release exceeded $2 \%$ at around $930^{\circ} \mathrm{C}$ in the experiment with air before fuel operation. The oxygen release was very similar when $5 \%$ oxygen in nitrogen was used to fluidize the air reactor and in this experiment the reactor temperature was increased one step further up to around $950^{\circ} \mathrm{C}$. The oxygen release exceeded $3.5 \%$, but decreased continuously after the temperature reached $950^{\circ} \mathrm{C}$ and steady state was never reached. This implies that the point for $950^{\circ} \mathrm{C}$ might be an overestimation of the relevant oxygen concentration at this temperature.

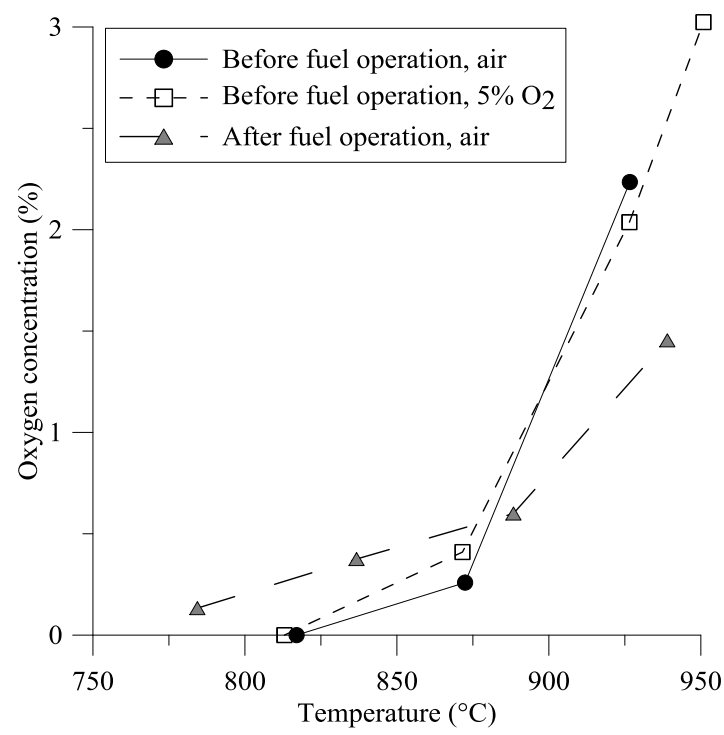

Figure 5. Oxygen release, equation (9), as a function of fuel reactor temperature during the oxygen release experiments with $\mathrm{Fe}_{0.66} \mathrm{Mn}_{1.33} \mathrm{SiO}_{3}$. The dots represent an average oxygen concentration during a period when the temperature was kept constant. These results were obtained during day $\mathrm{I}_{1: 2}$ and $\mathrm{VI}_{1: 2}$. 
The oxygen release experiment after fuel operation showed a somewhat different behavior of the oxygen carrier. In this case oxygen release was observed already at $750^{\circ} \mathrm{C}$. However, the oxygen release was lower than for the cases before fuel operation at higher temperatures. In all three cases the oxygen release increased substantially when the temperature exceeded $900^{\circ} \mathrm{C}$.

Three oxygen release experiments were also carried out with $\mathrm{FeMnSiO}_{3}$, see Figure 6. Oxygen release was observed at temperatures above $800^{\circ} \mathrm{C}$ in all three experiments. In the experiment with air before fuel operation oxygen release could be observed even below $800^{\circ} \mathrm{C}$. As can be seen in the figure, a large increase in oxygen release was observed when the temperature exceeded $900^{\circ} \mathrm{C}$. However, when the highest temperature was kept constant the measured oxygen concentration decreased as a function of time.

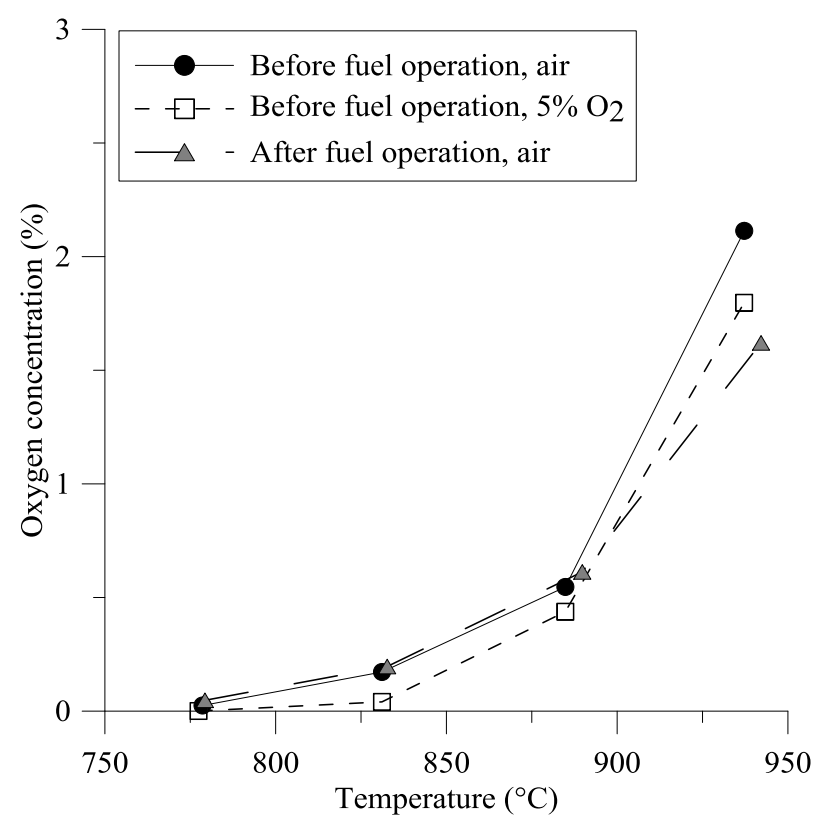

Figure 6. Oxygen release, equation (9), as a function of fuel reactor temperature during the oxygen release experiments with $\mathrm{FeMnSiO}_{3}$. The dots represent an average oxygen concentration during a period when the temperature was kept constant. These results were obtained during day $\mathrm{I}_{1: 1}, \mathrm{II}_{1: 1}$ and $\mathrm{VI}_{1: 1}$.

Also in this case no significant difference in oxygen release could be seen when the air reactor was fluidized with $5 \%$ oxygen in nitrogen instead of air. For $\mathrm{FeMnSiO}_{3}$, there was only a minor difference in oxygen release for the fresh particles and the particles that had been exposed to fuel operation. This difference was mainly seen at the highest temperature level. Overall, $\mathrm{FeMnSiO}_{3}$ showed lower oxygen release than $\mathrm{Fe}_{0.66} \mathrm{Mn}_{1.33} \mathrm{SiO}_{3}$ at temperatures above $900^{\circ} \mathrm{C}$, which is in conformity with what was seen for these materials in CLOU experiments in a batch fluidized bed reactor [26].

The very small difference in oxygen release between fluidizing the air reactor with air or 5\% oxygen in nitrogen can be explained by the fact that the oxidation reaction is a phase transition of 
the oxygen carrier. This results in approximately equal oxygen release behavior suggesting that the residence time and the oxygen concentration in the air reactor are sufficient to give a phase transition. This behavior differs from some other oxygen carrier materials such as perovskite materials, for which the degree of oxidation is strongly dependent on the oxygen partial pressure [30].

\subsection{Fuel Operation with Natural Gas}

The fuel flow, fuel reactor temperature and $\mathrm{CO}_{2}$ yield during the natural gas operation with $\mathrm{Fe}_{0.66} \mathrm{Mn}_{1.33} \mathrm{SiO}_{3}$ are shown in Figure 7. The vertical lines indicate a new day of experiment. The air flow was kept constant at $7 \mathrm{~L}_{\mathrm{N}} / \mathrm{min}$. The temperature was increased stepwise during the first day and the $\mathrm{CO}_{2}$ yield increased for each temperature increase. The $\mathrm{CO}_{2}$ yield reached 1 when the temperature was approximately $950^{\circ} \mathrm{C}$. Even when the fuel conversion was complete no oxygen was measured in the outlet of the fuel reactor. Since full fuel conversion was reached, the fuel flow was increased from $0.3 \mathrm{~L}_{\mathrm{N}} / \mathrm{min}$ to $0.4 \mathrm{~L}_{\mathrm{N}} / \mathrm{min}$ during the second day. $0.3 \mathrm{LN} / \mathrm{min}$ corresponds to a thermal power of $220 \mathrm{~W}$ and $0.4 \mathrm{~L}_{\mathrm{N}} / \mathrm{min}$ corresponds to a thermal power of 290 W. The $\mathrm{CO}_{2}$ yield was only slightly decreased for the higher fuel flow. Shortly after the fuel flow was increased, there were difficulties with the circulation and the fuel flow was stopped for a short period. The longer fuel stop later during the same day was intentional and was not caused by any operational problems.

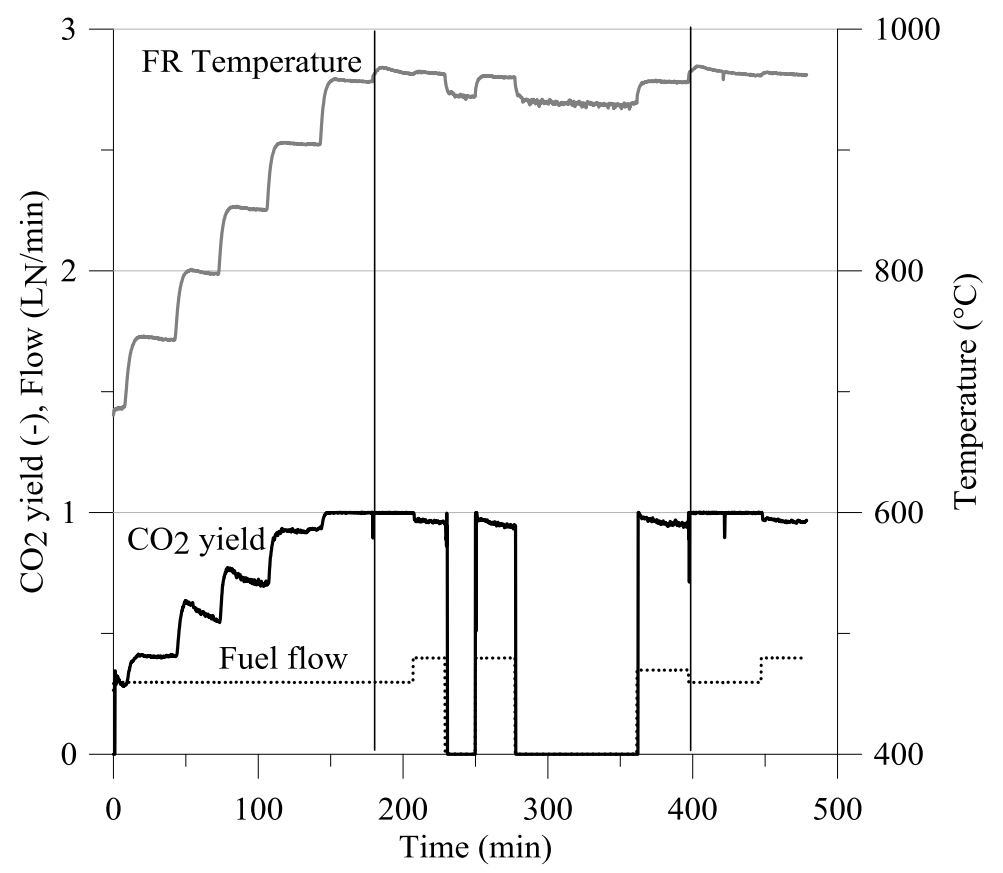

Figure 7. Fuel flow, $\mathrm{CO}_{2}$ yield and fuel reactor temperature as a function of time during the natural gas operation with $\mathrm{Fe}_{0.66} \mathrm{Mn}_{1.33} \mathrm{SiO}_{3}$. The vertical lines indicate a new day of experiment. These results were obtained during day $\mathrm{III}_{1: 2}, \mathrm{IV}_{1: 2}$ and $\mathrm{V}_{1: 2}$.

The particle inventory was increased with $25 \%$ from $200 \mathrm{~g}$ to $250 \mathrm{~g}$ for the third day with natural gas operation. There was no significant increase in performance for fuel flows of 0.3 and 0.4 
$\mathrm{L}_{\mathrm{N}} / \mathrm{min}$. This means that the fuel reactor was operated with a solids inventory corresponding to approximately $180 \mathrm{~kg} / \mathrm{MW}$ and $235 \mathrm{~kg} / \mathrm{MW}$ during the first two days and with a solids inventory corresponding to approximately $225 \mathrm{~kg} / \mathrm{MW}$ and $295 \mathrm{~kg} / \mathrm{MW}$ during the third day. However, towards the end of the third day there were problems with the circulation of solids and the experiment was aborted. The circulation problems were most likely caused by large loss of fines leading to insufficient solids inventory.

An overview of the natural gas operation with $\mathrm{FeMnSiO}_{3}$ can be seen in Figure 8. The vertical lines indicate a new day of experiment. During the first day, the relation between fuel reactor temperature and combustion performance was investigated. The air flow was initially set to 6 $\mathrm{L}_{\mathrm{N}} /$ min, but was increased to $7 \mathrm{~L}_{\mathrm{N}} / \mathrm{min}$ after 48 min of operation. This air flow was then kept constant during the remaining experiments with natural gas. As can be seen in the figure, the $\mathrm{CO}_{2}$ yield increased with increased temperature. A stepwise temperature increase was carried out at the two different air flows, but no major difference in combustion performance could be observed when the air flow was increased. During the second day the air flow was kept constant and the temperature was varied between $900^{\circ} \mathrm{C}$ and $1000^{\circ} \mathrm{C}$. The combustion performance was inferior as compared to $\mathrm{Fe}_{0.66} \mathrm{Mn}_{1.33} \mathrm{SiO}_{3}$. Since complete combustion could not be achieved, the fuel flow was not increased from $0.3 \mathrm{~L} / \mathrm{min}$ in this case. For the last two days of operation the inventory was increased with $25 \%$ from $240 \mathrm{~g}$ to $300 \mathrm{~g}$. Figure 8 shows that considerably higher $\mathrm{CO}_{2}$ yield was obtained during the last two days when the inventory was increased. The increase in solids inventory gave an approximate fuel reactor inventory of $355 \mathrm{~kg} / \mathrm{MW}$ instead of $285 \mathrm{~kg} / \mathrm{MW}$ for the lower solids inventory.

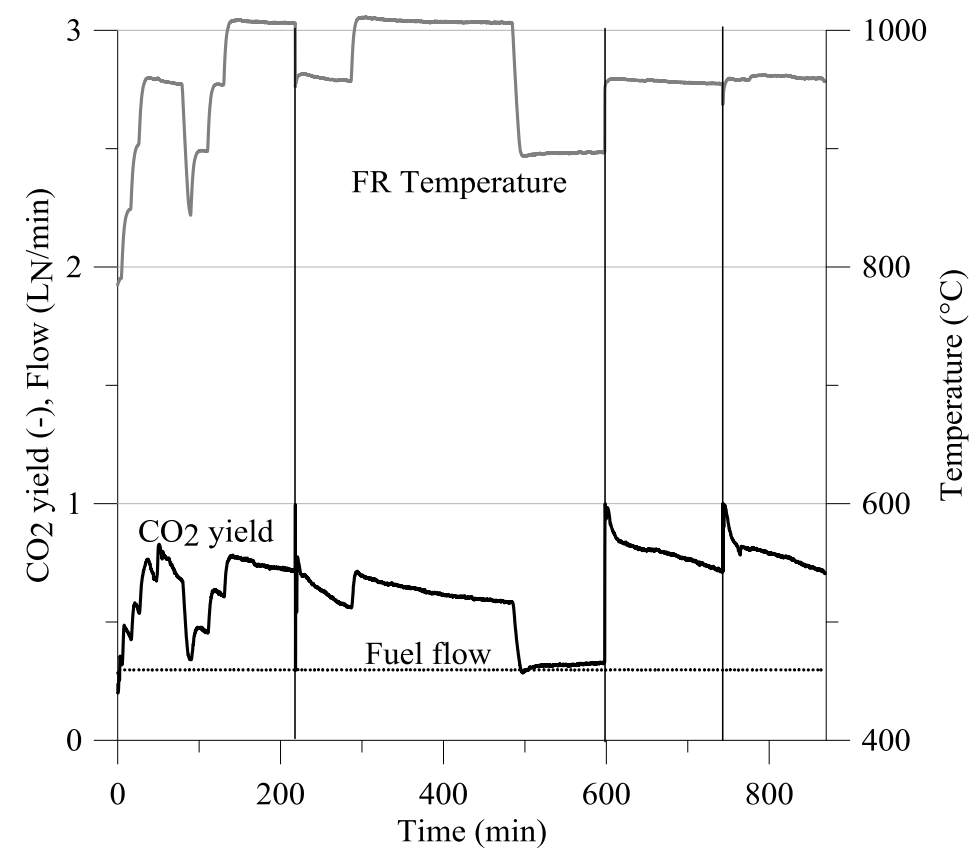

Figure 8. Fuel flow, $\mathrm{CO}_{2}$ yield and fuel reactor temperature as a function of time during the natural gas operation with $\mathrm{FeMnSiO}_{3}$. The vertical dashed lines indicate a new day of experiment. These results were obtained during day $\mathrm{III}_{1: 1}, \mathrm{IV}_{\mathrm{MS} 2}, \mathrm{~V}_{1: 1}$ and $\mathrm{VI}_{1: 1}$. 
In Figure 8, it may be worth taking notice of the peaks in $\mathrm{CO}_{2}$ yield during the first minutes of fuel operation during day $\mathrm{V}_{1: 1}$ and day $\mathrm{VI}_{1: 1}$. These peaks are magnified in Figure 9 where it can be seen that the decrease in combustion performance was initially very fast and then slowed down after approximately $15 \mathrm{~min}$. The initial fast decrease is believed to be caused by an overall reduction of the oxygen carrier particles, which would mean that the particles were farther oxidized after cool down and heat up in air than during continuous operation. This is not an unexpected behavior since oxidation of $(\mathrm{Fe}, \mathrm{Mn})_{3} \mathrm{O}_{4}$ to $(\mathrm{Fe}, \mathrm{Mn})_{2} \mathrm{O}_{3}$ is thermodynamically limited at higher temperatures, so the driving force for oxidation and reaction kinetics for oxidation may very well be slow at operational temperature. As is indicated in the phase diagram in Figure 2 for $\mathrm{MnFeSiO}_{3}$, there are no phase transitions possible at higher temperatures. This is in contrast to $\mathrm{Fe}_{0.66} \mathrm{Mn}_{1.33} \mathrm{SiO}_{3}$, where phase transitions which can release gaseous oxygen are possible at higher temperatures.

The high degree of oxidation provided high combustion performance initially, but the residence time or $\mathrm{O}_{2}$ partial pressure in the air reactor appears to have been insufficient to achieve complete reoxidation. This caused a decreasing degree of oxidation of the particles in the fuel reactor and thus a decreasing combustion performance. However, it would be expected that the combustion performance would reach steady state when the reduction of the particles in the fuel reactor matched the oxidation in the air reactor. The continuing decrease in $\mathrm{CO}_{2}$ yield, which has not stabilized after two hours, is not fully understood. However, it can be noted that the curves for day $\mathrm{V}_{1: 1}$ and day $\mathrm{VI}_{1: 1}$ are almost identical in Figure 9, which indicates that it is not a permanent degradation of the particles.

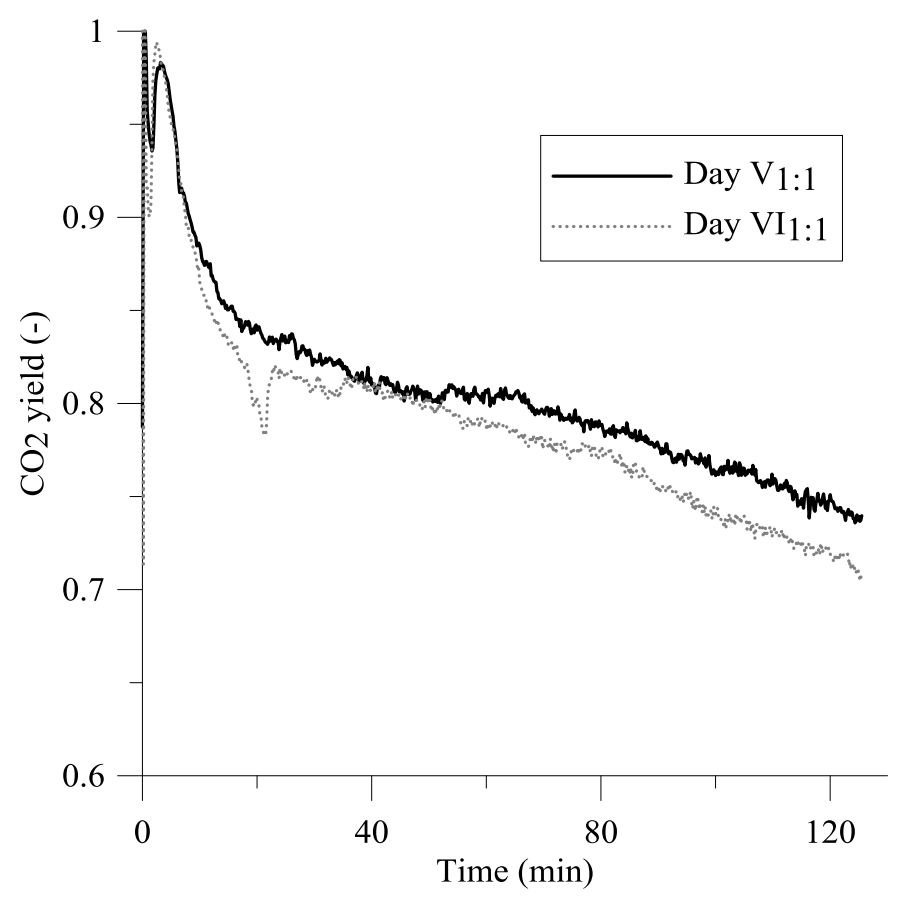

Figure 9. The $\mathrm{CO}_{2}$ yield as a function of time during the first 30 min of fuel operation with natural gas during day $\mathrm{V}_{1: 1}$ and day $\mathrm{VI}_{1: 1}$. 
The peaks in $\mathrm{CO}_{2}$ yield during the first minutes of fuel operation each day could not be clearly observed for $\mathrm{Fe}_{0.66} \mathrm{Mn}_{1.33} \mathrm{SiO}_{3}$. This indicated that the residence time in the air reactor during the experiments with $\mathrm{Fe}_{0.66} \mathrm{Mn}_{1.33} \mathrm{SiO}_{3}$ was sufficient to maintain a high oxidation degree.

By comparing Figure 7 and Figure 8, it can be seen that $\mathrm{Fe}_{0.66} \mathrm{Mn}_{1.33} \mathrm{SiO}_{3}$ provided much better combustion performance with natural gas than $\mathrm{FeMnSiO}_{3}$ did. The maximum $\mathrm{CO}_{2}$ yield as a function of fuel reactor temperature can be seen in Figure 10. The figure clearly shows that FeMnSiO 3 gave lower $\mathrm{CO}_{2}$ yields than $\mathrm{Fe}_{0.66} \mathrm{Mn}_{1.33} \mathrm{SiO}_{3}$ did for all temperature levels.

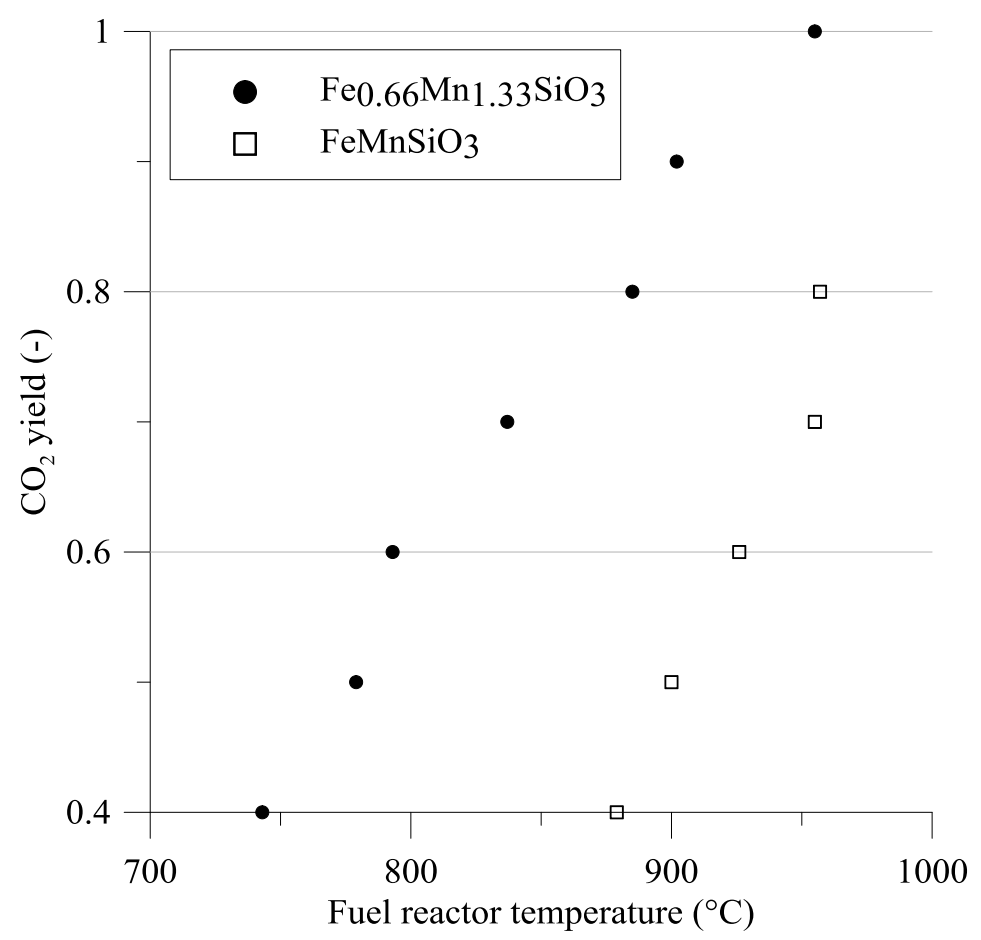

Figure 10. $\mathrm{CO}_{2}$ yield as a function of fuel reactor temperature during natural gas operation with a fuel flow of $0.3 \mathrm{LN} / \mathrm{min}$ and the lower particle inventories. These results were obtained during day $\mathrm{III}_{1: 2}, \mathrm{IV}_{1: 2}, \mathrm{III}_{1: 1}$ and $\mathrm{IV}_{1: 1}$.

\section{Fuel Operation with Syngas}

The fuel operation with syngas was carried out in periods of 15-20 minutes as explained in section 2.4. An overview of the syngas experiment with $\mathrm{Fe}_{0.66} \mathrm{Mn}_{1.33} \mathrm{SiO}_{3}$ can be seen in Figure 11 where the temperature was increased stepwise for each period of fuel addition. The temperature increased during fuel addition due to the exothermic reaction and decreased again when the fuel reactor was fluidized with air. As can be seen in the figure, the $\mathrm{CO}_{2}$ yield reached 1 when the temperature exceeded $800^{\circ} \mathrm{C}$. 


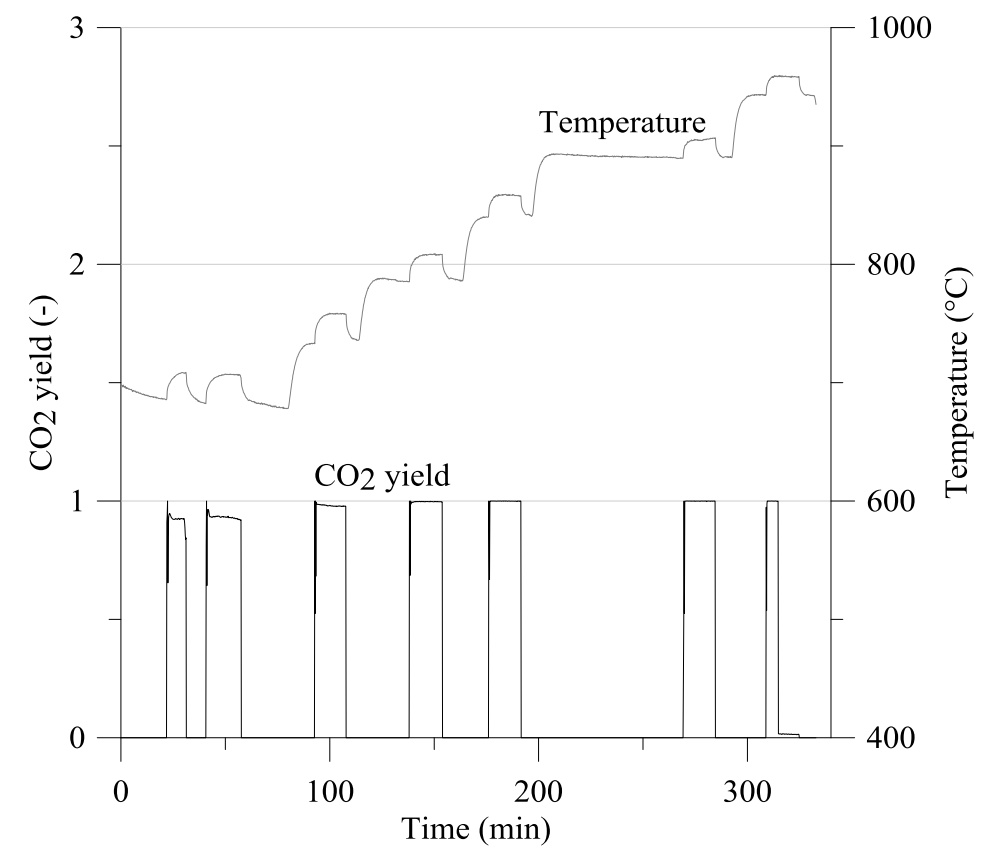

Figure 11. $\mathrm{CO}_{2}$ yield and fuel reactor temperature as a function of time during the syngas operation with $\mathrm{Fe}_{0.66} \mathrm{Mn}_{1.33} \mathrm{SiO}_{3}$. These results were obtained during day $\mathrm{II}_{1: 2}$.

The syngas operation with $\mathrm{FeMnSiO}_{3}$ was carried out in the same manner as the syngas experiment with $\mathrm{Fe}_{0.66} \mathrm{Mn}_{1.33} \mathrm{SiO}_{3}$. As can be seen in Figure 12, the conversion of syngas was much lower with $\mathrm{FeMnSiO}_{3}$ than with $\mathrm{Fe}_{0.66} \mathrm{Mn}_{1.33} \mathrm{SiO}_{3}$. The initial peaks in conversion for each period with syngas are likely explained by the particles being fully oxidized during the periods with air, where the average partial pressure of $\mathrm{O}_{2}$ which the particles are exposed to would increase and hence promoting oxidation. However, this effect can only be seen during the first couple of minutes for each syngas period. This is the same behavior as was observed during the last two days of natural gas operation with $\mathrm{FeMnSiO}_{3}$. Since the conversion of syngas never reached $100 \%$, it was possible to observe that the conversion increased for each temperature increase. 


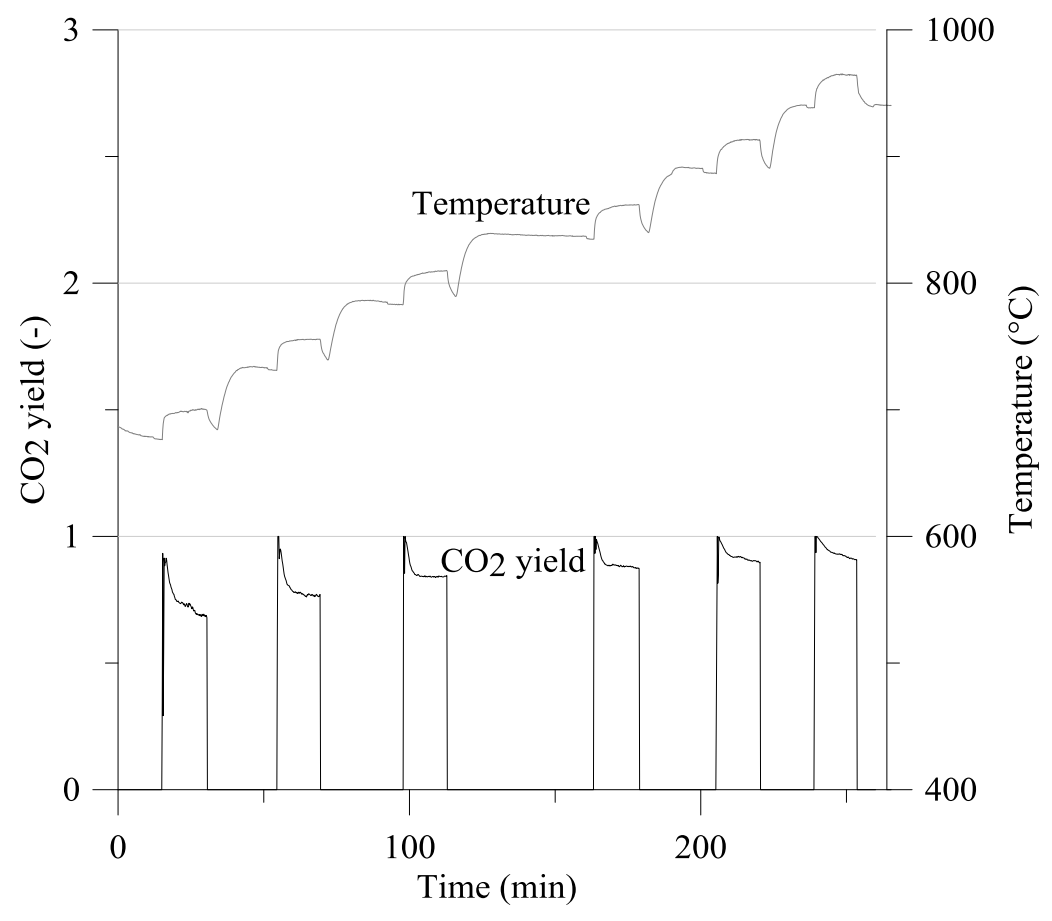

Figure 12. $\mathrm{CO}_{2}$ yield and fuel reactor temperature as a function of time during the syngas operation with $\mathrm{FeMnSiO}_{3}$. These results were obtained during day $\mathrm{VII}_{1: 1}$.

After the experiments with syngas calculations were carried out to check how much of the fuel that was oxidized during the periods when the fuel reactor was fluidized with air. This fraction varied between $0-3 \%$ and was not considered large enough to be significant in the evaluation of the results.

\subsection{Particle Attrition}

After the experiments with each material were finished, the reactor system was opened and the filters were emptied. After the experiments with $\mathrm{Fe}_{0.66} \mathrm{Mn}_{1.33} \mathrm{SiO}_{3}, 71 \%$ of the added particles were found in the reactor and after the experiments with $\mathrm{FeMnSiO}_{3} 82 \%$ of the added particles were found in the reactor. These numbers can indicate the extent of attrition if it is assumed that fines and smaller particles are more likely to be elutriated compared to larger ones. The majority of the missing particles could be found in the filters and some were found in the outlet pipes when these were cleaned. The change in size distribution for the particles recovered in the reactor, i.e. "used particles", can be seen in Figure 13 and Figure 14. In the last case shown in the figures, i.e. "used particles, assuming lost mass as fines", all particles which were not found in the reactor were assumed to be fines $(<45 \mu \mathrm{m})$. To verify this assumption, wet sieving was carried out with the material found in the filters and it was found that more than $99 \%$ of the material in the filters was below $45 \mu \mathrm{m}$. This indicated that even though the particles had quite low density, it was only fines that were carried away with the gas stream through the outlet pipes. The average attrition rate during fuel operation was $4.2 \% / \mathrm{h}$ for $\mathrm{Fe}_{0.66} \mathrm{Mn}_{1.33} \mathrm{SiO}_{3}$ and $1.2 \% / \mathrm{h}$ for $\mathrm{FeMnSiO}_{3}$, with the increase in particle inventory taken into account. 
The production of fines appears to be very large, especially for $\mathrm{Fe}_{0.66} \mathrm{Mn}_{1.33} \mathrm{SiO}_{3}$ which matches the high attrition index reported in Table 1. Almost no particles below $45 \mu \mathrm{m}$ were found in the reactor, so it could be concluded that particles of that size was blown out of the reactor system. For $\mathrm{FeMnSiO}_{3}$ there were very few particles left in the size range of 180-212 $\mu \mathrm{m}$, whereas for $\mathrm{Fe}_{0.66} \mathrm{Mn}_{1.33} \mathrm{SiO}_{3}$ around $50 \%$ of the mass in this range was left. The particles in the size interval above $212 \mu \mathrm{m}$ in the figures might be explained by formation of microagglomerates since no particles in this size interval were added to the system.

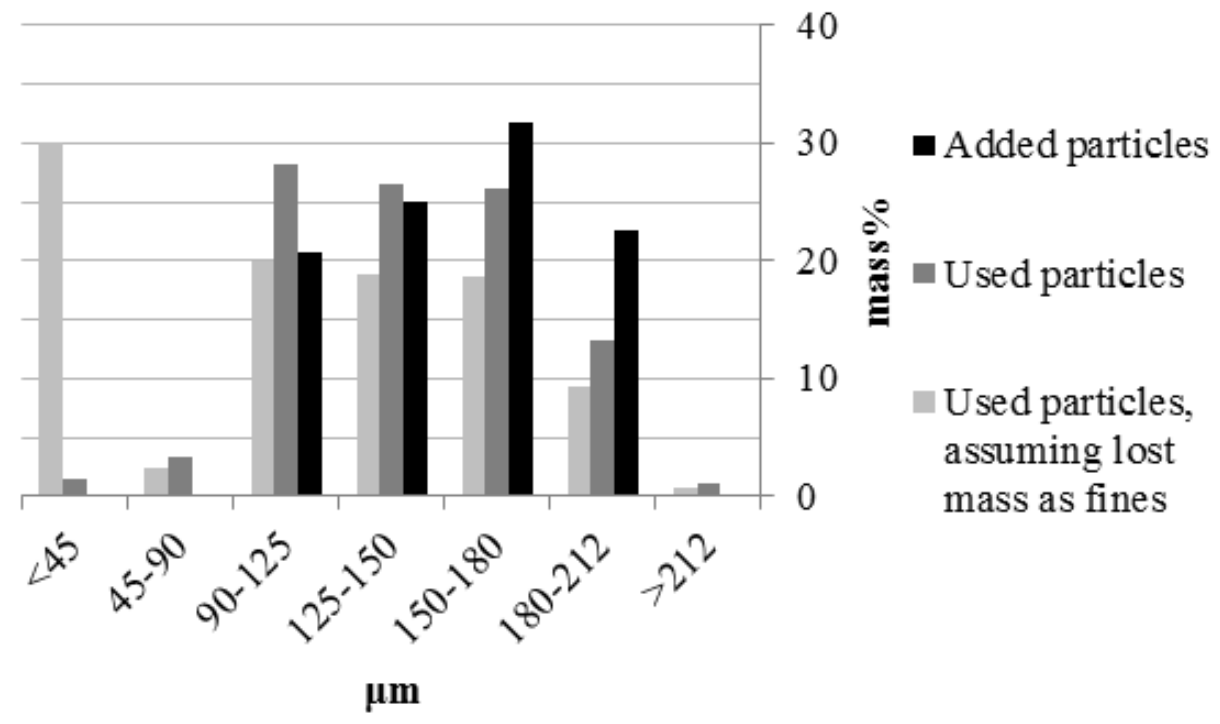

Figure 13. The size distribution of $\mathrm{Fe}_{0.66} \mathrm{Mn}_{1.33} \mathrm{SiO}_{3}$ before experiments, after experiments and after experiments with all assumed fines included.

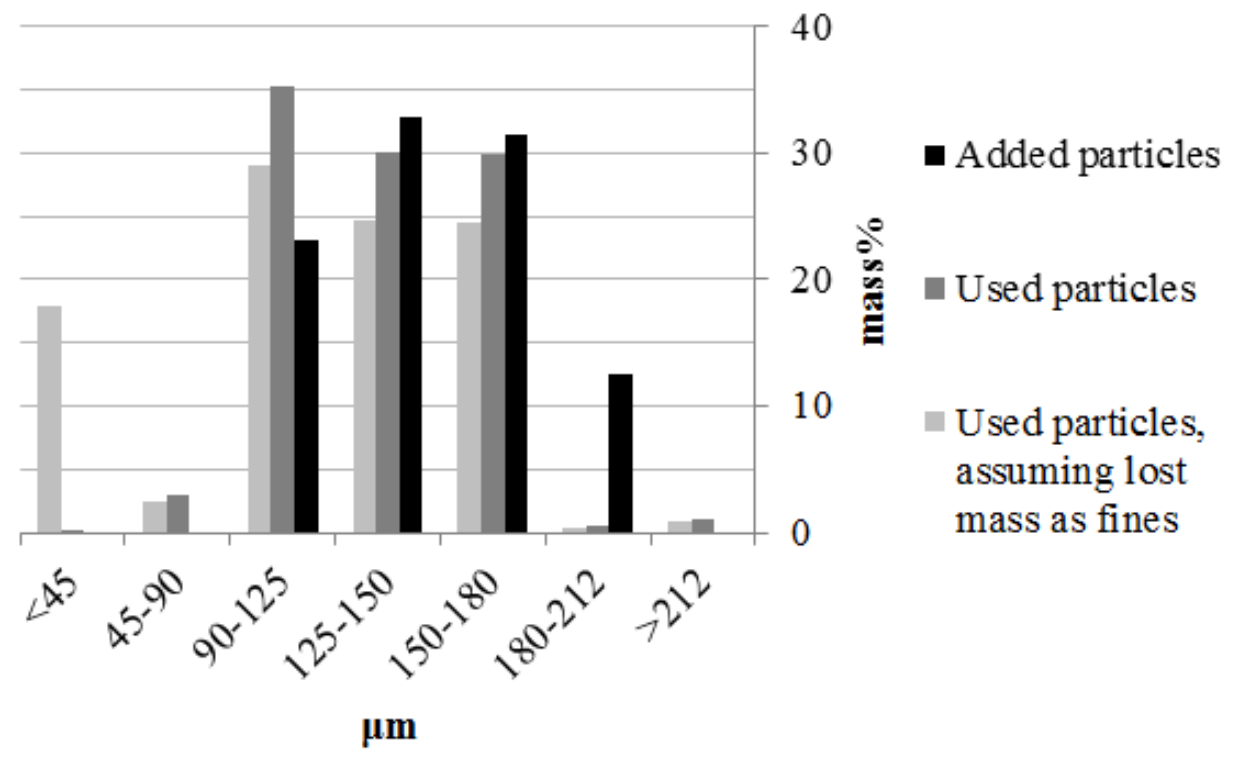

Figure 14. The size distribution of $\mathrm{FeMnSiO}_{3}$ before experiments, after experiments and after experiments with all assumed fines included. 


\section{Discussion}

The results presented above state quite clearly that $\mathrm{Fe}_{0.66} \mathrm{Mn}_{1.33} \mathrm{SiO}_{3}$ had a much better ability to convert the fuel than $\mathrm{FeMnSiO}_{3}$ had. This was shown to be valid for operation with both natural gas and syngas and at all investigated temperatures. For example, a $\mathrm{CO}_{2}$ yield of 0.9 was reached with $\mathrm{Fe}_{0.66} \mathrm{Mn}_{1.33} \mathrm{SiO}_{3}$ at $900^{\circ} \mathrm{C}$ while a $\mathrm{CO}_{2}$ yield of 0.5 was reached with $\mathrm{FeMnSiO}_{3}$ at the same temperature, see Figure 10. It should be noted that at the same temperature both oxygen carrier materials released oxygen at a concentration of 1\% in inert atmosphere, see Figure 5 andFigure 6. Since one material performed much better in fuel experiments, but both materials performed equally in oxygen release experiments, it could be suspected that gas-gas reactions are not the main route for fuel conversion. The conclusion would then be that the ability to release oxygen of these materials is not the decisive property for their performance as oxygen carriers. Another possibility would be that the oxygen release behavior under inert conditions is controlled by equilibrium and not by kinetics. The presence of fuel which reduces or removes the oxygen from the surroundings may then cause a rapid increase in oxygen release. The phase diagram for MnO$\mathrm{FeO}-\mathrm{SiO}$ with varying oxygen concentration can be seen in Figure 15. The phase diagram has been calculated with the software FactSage 6.3 using the FToxid database. The phases marked with solid lines and varying shades of grey are valid at $900^{\circ} \mathrm{C}$ and the phases marked by dashed lines are valid at $950^{\circ} \mathrm{C}$. As can be seen in the figure, the equilibrium oxygen concentration for the phase changes increases with temperature. This dependency is reflected in the results from the oxygen release experiments where the concentration of oxygen released increased with temperature.

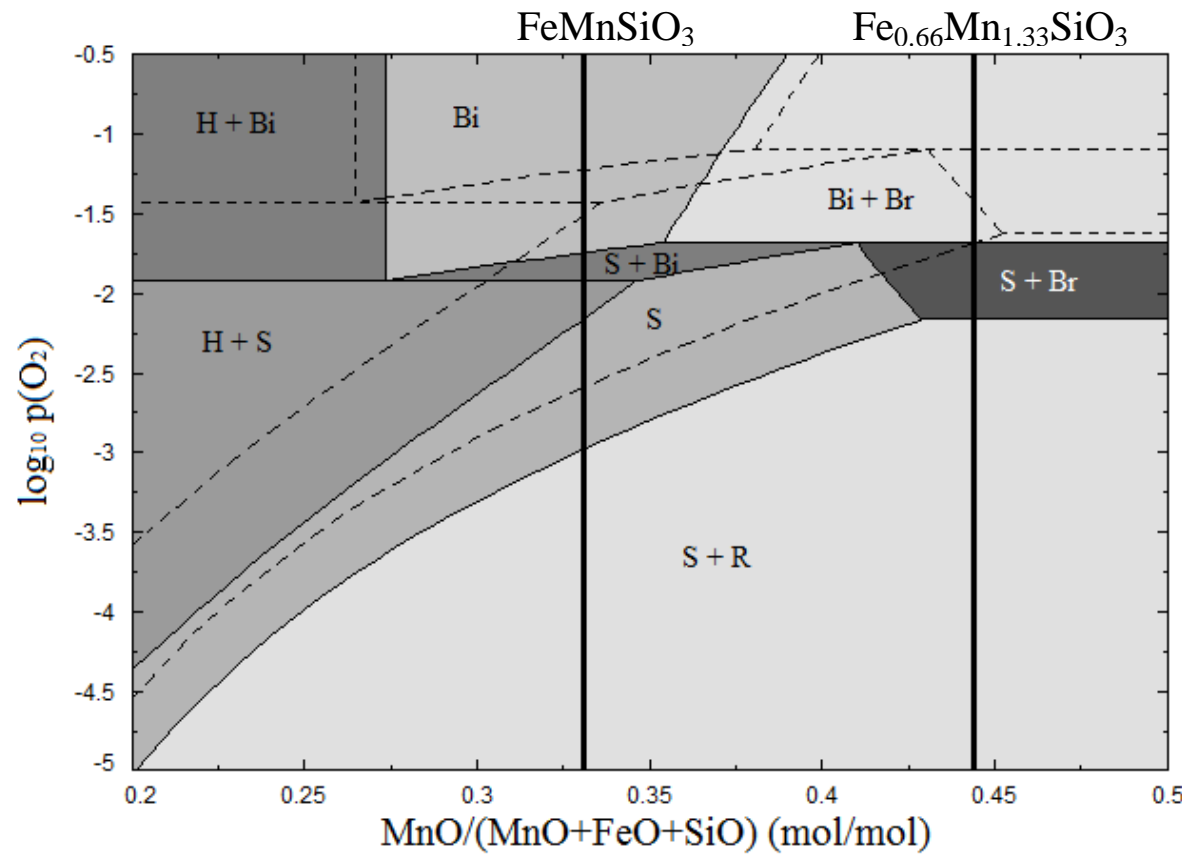

Bi : Bixbyite, $\left(\mathrm{Mn}_{\mathrm{x}} \mathrm{Fe}_{1-\mathrm{x}}\right)_{2} \mathrm{O}_{3}$

$\mathrm{Br}$ : Braunite, $\mathrm{Mn}_{7} \mathrm{SiO}_{12}$

$\mathrm{H}$ : Hematite, $\left(\mathrm{Fe}_{\mathrm{x}} \mathrm{Mn}_{1-\mathrm{x}}\right)_{2} \mathrm{O}_{3}$

$\mathrm{R}$ : Rhodonite, $\mathrm{MnSiO}_{3}$

$\mathrm{S}:$ Spinel, $\left(\mathrm{Mn}_{\mathrm{x}} \mathrm{Fe}_{1-\mathrm{x}}\right)_{3} \mathrm{O}_{4}$

Figure 15. Phase diagram of $\mathrm{MnO}-\mathrm{FeO}-\mathrm{SiO}$ at $900^{\circ} \mathrm{C}$ marked with solids lines and different shades of grey and at $950^{\circ} \mathrm{C}$ marked only with dashed lines. The molar fraction of silica is fixed at $33 \%$. Silica is also present as various forms of $\mathrm{SiO}_{2}$, but these are not marked in the phase diagram. The vertical lines denote the composition of the oxygen carriers studied in this work. 
Figure 15 indicates that the transition from braunite to rhodonite, see reaction (5), would not occur for $\mathrm{Fe}_{0.66} \mathrm{Mn}_{1.33} \mathrm{SiO}_{3}$ at oxygen release experiments at $900^{\circ} \mathrm{C}$ when the oxygen concentration was around $1 \%$ (-2 in the figure). However, if the oxygen concentration is only slightly lower than $1 \%$, which would probably be the case during fuel operation, this phase change would occur with gas phase oxygen release. The same reasoning cannot be applied to $\mathrm{FeMnSiO}_{3}$ and this could explain the much higher fuel conversion with $\mathrm{Fe}_{0.66} \mathrm{Mn}_{1.33} \mathrm{SiO}_{3}$. However, it is not possible to assess the relative importance of gas-gas reactions and gas-solid reaction from the experiments conducted in this study.

The oxygen concentration in the air reactor during the fuel operation was around $10 \%$. At this oxygen concentration and temperatures around $900^{\circ} \mathrm{C}$ the stable phases for $\mathrm{Fe}_{0.66} \mathrm{Mn}_{1.33} \mathrm{SiO}_{3}$ are bixbyite and braunite and for $\mathrm{FeMnSiO}_{3}$ it is only bixbyite. When the materials are transported to the fuel reactor the transition from bixbyite to spinel, see reaction (4), should occur for both materials and causing a release of oxygen. For $\mathrm{Fe}_{0.66} \mathrm{Mn}_{1.33} \mathrm{SiO}_{3}$ also reaction (5) from braunite to rhodonite could occur and release oxygen.

The iron-manganese-silica oxygen carriers examined in this study can be compared to a previously investigated iron-manganese oxygen carrier material. A manganese-iron oxygen carrier with $66.8 \mathrm{wt} \%$ iron oxides and $33.2 \mathrm{wt} \%$ manganese oxides has previously been studied in this reactor unit by Rydén et.al. [25]. The $\mathrm{CO}_{2}$ yield reported for this material was 0.96 at a temperature of $950^{\circ} \mathrm{C}$ and a fuel flow of $0.3 \mathrm{~L}_{\mathrm{N}} / \mathrm{min}$. The material collapsed after $4 \mathrm{~h}$ of fuel operation and turned into a fine dust. The $\mathrm{CO}_{2}$ yield at the same temperature and fuel flow was higher for $\mathrm{Fe}_{0.66} \mathrm{Mn}_{1.33} \mathrm{SiO}_{3}$ but was lower for $\mathrm{FeMnSiO}_{3}$, see Figure 10. Both the investigated iron-manganese-silica materials could be operated for longer periods with fuel and the majority of the particles remained in the reactor system. This is promising results and shows that the combination of iron, manganese and silica is relevant for oxygen carrier materials even though the mechanical stability of the materials should be investigated further. 


\section{Conclusions}

The combined oxides $\mathrm{Fe}_{0.66} \mathrm{Mn}_{1.33} \mathrm{SiO}_{3}$ and $\mathrm{FeMnSiO}_{3}$ have been examined as oxygen carrier materials for chemical-looping combustion in continuous operation. The conversions of natural gas and syngas were investigated, as well as oxygen release behavior. Both materials released oxygen at temperatures between $800-950^{\circ} \mathrm{C}$ and the oxygen release increased with temperature. $\mathrm{Fe}_{0.66} \mathrm{Mn}_{1.33} \mathrm{SiO}_{3}$ and $\mathrm{FeMnSiO}_{3}$ released oxygen at approximately equal concentration in the investigated temperature interval. $\mathrm{Fe}_{0.66} \mathrm{Mn}_{1.33} \mathrm{SiO}_{3}$ had higher conversion of natural gas than $\mathrm{FeMnSiO}_{3}$ did and the conversion increased with temperature for both materials. During natural gas operation with $\mathrm{Fe}_{0.66} \mathrm{Mn}_{1.33} \mathrm{SiO}_{3}$ the conversion reached $100 \%$ at around $950^{\circ} \mathrm{C}$ with a fuel flow of $0.3 \mathrm{~L}_{\mathrm{N}} / \mathrm{min}$. The conversion increased when the particle inventory was increased, this could especially be seen for $\mathrm{FeMnSiO}_{3}$ as the conversion was rather low. The conversion of syngas was much higher during operation with $\mathrm{Fe}_{0.66} \mathrm{Mn}_{1.33} \mathrm{SiO}_{3}$ than during operation with $\mathrm{FeMnSiO}_{3}$. The conversion of syngas increased with temperature for both materials and full conversion was reached above $800^{\circ} \mathrm{C}$ for $\mathrm{Fe}_{0.66} \mathrm{Mn}_{1.33} \mathrm{SiO}_{3}$. Full conversion was never reached during syngas operation with $\mathrm{FeMnSiO}_{3}$. Both materials had rather large elutriation of fines and a significant change in particle size distribution could be observed.

It can be concluded that both $\mathrm{Fe}_{0.66} \mathrm{Mn}_{1.33} \mathrm{SiO}_{3}$ and $\mathrm{FeMnSiO}_{3}$ are oxygen carriers with CLOU properties, i.e. having the ability to release oxygen in the fuel reactor. $\mathrm{Fe}_{0.66} \mathrm{Mn}_{1.33} \mathrm{SiO}_{3}$ would be preferred as it was able to reach full conversion of both syngas and natural gas, but the particle attrition was clearly too high.

The results are highly interesting as they demonstrate that combined oxides of iron, manganese and silica can give highly reactive oxygen carriers with the ability to release oxygen. This opens two interesting options. One could be the use of naturally occurring ores, as it is not uncommon with manganese ores with high concentrations of iron and silica. Another possibility is of course the manufacture of highly reactive oxygen carrier materials from low cost raw materials, e.g. natural ores.

Consequently, the combination of high performance with potential low cost of the raw materials would strongly motivate further study of these materials to investigate if material integrity can be improved.

\section{Acknowledgements}

The research leading to these results has received funding from the Seventh Framework Programme under grant agreement $\mathrm{n}^{\circ} 241401$. 


\section{References}

1. IPCC, Contribution of Working Group I to the Fourth Assessment Report of the Intergovernmental Panel on Climate Change, S. Solomon, et al., Editors. 2007: Cambridge, United Kingdom and New York, USA.

2. IPCC, IPCC Special Report on Carbon Dioxide Capture and Storage, B. Metz, et al., Editors. 2005: Cambridge, United Kingdom.

3. Lyngfelt, A., Oxygen Carriers for Chemical Looping Combustion - $4000 \mathrm{~h}$ of Operational Experience. Oil \& Gas Science and Technology, 2011. 66: p. 2.

4. Adanez, J., et al., Progress in Chemical-Looping Combustion and Reforming technologies. Progress in Energy and Combustion Science, 2012. 38(2): p. 215-282.

5. Mattisson, T., A. Lyngfelt, and H. Leion, Chemical-looping with oxygen uncoupling for combustion of solid fuels. International Journal of Greenhouse Gas Control, 2009. 3(1): p. 11-19.

6. Abad, A., et al., Demonstration of chemical-looping with oxygen uncoupling (CLOU) process in a 1.5kWth continuously operating unit using a Cu-based oxygen-carrier. International Journal of Greenhouse Gas Control, 2012. 6(0): p. 189-200.

7. Azimi, G., et al., (MnzFel-z)yOx combined oxides as oxygen carrier for chemical-looping with oxygen uncoupling. AIChE Journal, 2013. 59(2): p. 582-588.

8. Källén, M., et al., CaMn $n_{0.9} M_{0.103-\delta}$ as Oxygen Carrier in a Gas-Fired $10 \mathrm{~kW}_{\text {th }}$ ChemicalLooping Combustion Unit. Industrial \& Engineering Chemistry Research, 2013. 52 p. 6923-6932.

9. Linderholm, C., T. Mattisson, and A. Lyngfelt, Long-term integrity testing of spray-dried particles in a 10-kW chemical-looping combustor using natural gas as fuel. Fuel, 2009. 88(11): p. 2083-2096.

10. de Diego, L.F., et al., Reduction and Oxidation Kinetics of a CaMn ${ }_{0.9} \mathrm{Mg}_{0.1} \mathrm{O}_{3-\delta}$ Oxygen Carrier for Chemical-Looping Combustion. Ind. Eng. Chem. Res., 2014. 53: p. 87-103.

11. Mattisson, T., et al., Reactivity of a spray-dried NiO/NiAl2O4 oxygen carrier for chemical-looping combustion. Chemical Engineering Science, 2011. 66(20): p. 46364644.

12. Kolbitsch, P., et al., Operating experience with chemical looping combustion in a $120 \mathrm{~kW}$ dual circulating fluidized bed (DCFB) unit. International Journal of Greenhouse Gas Control, 2010. 4(2): p. 180-185.

13. Mayer, $\mathrm{K}$. , et al., Performance of $\mathrm{CaMn} 0.9 \mathrm{Mg}_{0.1} \mathrm{O}_{3-\delta}$ as oxygen carrier in Chemical Looping Combustion, a pilot study under realistic conditions accompanied by kinetic observations. Manuscript in preparation for Industrial \& Engineering Chemistry Research.

14. Jerndal, E., T. Mattisson, and A. Lyngfelt, Thermal Analysis of Chemical-Looping Combustion. Chemical Engineering Research and Design, 2006. 84(9): p. 795-806.

15. Lyngfelt, A. and T. Mattisson, Materials for chemical-looping combustion, in Power Engineering for CCS Power Plants2011, WILEY-VCH Verlag.

16. Rydén, M., et al., Combined oxides as oxygen-carrier material for chemical-looping with oxygen uncoupling. Applied Energy, 2013. 113: p. 1924-1932.

17. Jing, D., et al., Manganese-silica combined oxides as oxygen carrier for chemical-looping combustion, in 2nd International Conference on Chemical Looping2012: Darmstadt.

18. Lambert, A., et al., Synthesis and characterization of bimetallic Fe/Mn oxides for chemical looping combustion. Energy Procedia, 2009. 1: p. 375-381. 
19. Shulman, A., et al., Manganese/Iron, Manganese/Nickel, and Manganese/Silicon Oxides Used in Chemical-Looping With Oxygen Uncoupling (CLOU) for Combustion of Methane. Energy \& Fuels, 2009. 23: p. 5269-5275.

20. Wickham, D.G., The chemical composition of spinels in the system Fe3O4Mn3O4. Journal of Inorganic and Nuclear Chemistry, 1969. 31(2): p. 313-320.

21. Crum, J.V., B.J. Riley, and J.D. Vienna, Binary phase diagram of the manganese oxideiron oxide system. Journal of the American Ceramic Society, 2009. 92(10): p. 2378-2384.

22. Kjellqvist, L. and M. Selleby, Thermodynamic assessment of the Fe-Mn-O system. Journal of Phase Equilibria and Diffusion, 2010. 31(2): p. 113-134.

23. Azimi, G., et al., Chemical-looping with oxygen uncoupling using combined Mn-Fe oxides, testing in batch fluidized bed. Energy Procedia, 2011. 4: p. 370-377.

24. Azimi, G., et al., Investigation of different Mn-Fe oxides as oxygen carrier for chemicallooping with oxygen uncoupling (CLOU). Energy and Fuels, 2013. 27(1): p. 367-377.

25. Rydén, M., A. Lyngfelt, and T. Mattisson, Combined manganese/iron oxides as oxygen carrier for chemical looping combustion with oxygen uncoupling (CLOU) in a circulating fluidized bed reactor system. Energy Procedia, 2011. 4: p. 341-348.

26. Mattisson, T., et al., Using $\left(\mathrm{Mn}_{x} \mathrm{Fe}_{1-x}\right)_{2} \mathrm{SiO}_{5}$ as oxygen carriers for chemical-looping with oxygen uncoupling (CLOU). Submitted for publication, 2013.

27. Rydén, M., et al., Measuring attrition resistance of oxygen carrier particles for chemical looping combustion with a customized jet cup. Powder Technology, 2014.

28. Moldenhauer, P., et al., Chemical-looping combustion and chemical-looping with oxygen uncoupling of kerosene with $\mathrm{Mn}$ - and Cu-based oxygen carriers in a circulating fluidizedbed 300 W laboratory reactor. Fuel Processing Technology, 2012. 104: p. 378-389.

29. Rydén, M. and M. Arjmand, Continuous hydrogen production via the steam-iron reaction by chemical looping in a circulating fluidized-bed reactor. International Journal of Hydrogen Energy, 2012. 37(6): p. 4843-4854.

30. Leonidova, E.I., et al., Oxygen non-stoichiometry, high-temperature properties, and phase diagram of CaMnO 3- $\delta$. Journal of Solid State Electrochemistry, 2011. 15(5): p. 1071-1075. 